\title{
Factors Associated with Post-Transplant Active Epstein-Barr Virus Infection and Lymphoproliferative Disease in Hematopoietic Stem Cell Transplant Recipients: A Systematic Review and Meta-Analysis
}

\author{
Pascal Roland Enok Bonong ${ }^{1}{ }^{\mathbb{D}}$, Monica Zahreddine ${ }^{1}$, Chantal Buteau $^{2}$, Michel Duval ${ }^{3}$, Louise Laporte ${ }^{4}$, \\ Jacques Lacroix ${ }^{5}$, Caroline Alfieri ${ }^{6}$ and Helen Trottier ${ }^{1, *}$ (D)
}

1 Department of Social and Preventive Medicine, Université de Montréal, CHU Sainte-Justine, Montréal, QC H3T 1C5, Canada; pascal.roland.enok.bonong@umontreal.ca (P.R.E.B.); monica.zahreddine@umontreal.ca (M.Z.)

2 Department of Pediatrics, Division of Infectious Diseases, CHU Sainte-Justine, Université de Montréal, Montréal, QC H3T 1C5, Canada; chantal.buteau.hsj@ssss.gouv.qc.ca

3 Department of Pediatrics, Division of Hematology-Oncology, CHU Sainte-Justine, Université de Montréal, Montréal, QC H3T 1C5, Canada; michel.duval@umontreal.ca

4 Research Center of CHU Sainte-Justine, Montréal, QC H3T 1C5, Canada; louise.laporte.hsj@ssss.gouv.qc.ca

5 Department of Pediatrics, Division of Pediatric Intensive Care Medicine, CHU Sainte-Justine,

check for updates

Citation: Enok Bonong, P.R.; Zahreddine, M.; Buteau, C.; Duval, M.; Laporte, L.; Lacroix, J.; Alfieri, C.; Trottier, H. Factors Associated with Post-Transplant Active Epstein-Barr Virus Infection and

Lymphoproliferative Disease in Hematopoietic Stem Cell Transplant Recipients: A Systematic Review and Meta-Analysis. Vaccines 2021, 9, 288. https://doi.org/10.3390/

vaccines 9030288

Academic Editor: Oliver Witzke

Received: 25 January 2021

Accepted: 15 March 2021

Published: 19 March 2021

Publisher's Note: MDPI stays neutral with regard to jurisdictional claims in published maps and institutional affiliations.

Copyright: ( $\odot 2021$ by the authors Licensee MDPI, Basel, Switzerland. This article is an open access article distributed under the terms and conditions of the Creative Commons Attribution (CC BY) license (https:// creativecommons.org/licenses/by/ $4.0 /)$.
Université de Montréal, Montréal, QC H3T 1C5, Canada; jacques.lacroix.med@ssss.gouv.qc.ca

6 Departement of Microbiology, Infectiology and Immunology, Université de Montréal,

CHU Sainte-Justine Research Center, Montréal, QC H3T 1C5, Canada; carolina.alfieri@umontreal.ca

* Correspondence: helen.trottier@umontreal.ca; Tel.: +1-(514)-345-4931

\begin{abstract}
This systematic review was undertaken to identify risk factors associated with posttransplant Epstein-Barr virus (EBV) active infection and post-transplant lymphoproliferative disease (PTLD) in pediatric and adult recipients of hematopoietic stem cell transplants (HSCT). A literature search was conducted in PubMed and EMBASE to identify studies published until 30 June 2020. Descriptive information was extracted for each individual study, and data were compiled for individual risk factors, including, when possible, relative risks with 95\% confidence intervals and/or $p$-values. Meta-analyses were planned when possible. The methodological quality and potential for bias of included studies were also evaluated. Of the 3362 titles retrieved, 77 were included (62 for EBV infection and 22 for PTLD). The overall quality of the studies was strong. Several risk factors were explored in these studies, but few statistically significant associations were identified. The use of anti-thymocyte globulin (ATG) was identified as the most important risk factor positively associated with post-transplant active EBV infection and with PTLD. The pooled relative risks obtained using the random-effect model were 5.26 (95\% CI: 2.92-9.45) and 4.17 (95\% CI: 2.61-6.68) for the association between ATG and post-transplant EBV infection and PTLD, respectively. Other risk factors for EBV and PTLD were found in the included studies, such as graft-versus-host disease, type of conditioning regimen or type of donor, but results are conflicting. In conclusion, the results of this systematic review indicate that ATG increases the risk of EBV infection and PTLD, but the link with all other factors is either nonexistent or much less convincing.
\end{abstract}

Keywords: Epstein-Barr virus (EBV); human herpesvirus-4 (HHV-4); risk factors; post-transplant lymphoproliferative disease (PTLD); EBV reactivation; hematopoietic stem cell transplant (HSCT)

\section{Introduction}

Hematopoietic stem cell transplant (HSCT) recipients are at risk of developing posttransplant lymphoproliferative disease (PTLD) following primary or reactivated infection by the Epstein-Barr virus (EBV) [1-7]. EBV is a ubiquitous human herpesvirus with a seroprevalence approximating $50-55 \%$ of the pediatric population living in countries with high 
hygienic standards and reaching $90-99 \%$ by mid-adulthood [8-10]. EBV is the etiologic agent of infectious mononucleosis and is also associated with the development of some cancers, most notably Hodgkin's lymphoma, African Burkitt's lymphoma and nasopharyngeal carcinoma [11-13], as well as lymphoproliferative disease in immunocompromised individuals [14]. After primary infection, EBV establishes latent infection in B cells [15]. In immunocompetent individuals, primary infection is often subclinical and latent infection is usually well controlled by the immune system throughout life. However, when the cytolytic T-lymphocyte arm of the immune system is suppressed, primary infection can be more consequential, and latent EBV can reactivate to cause a spectrum of EBV-associated diseases ranging from fever, EBV end-organ diseases, such as pneumonia, hepatitis and encephalitis, to PTLD [16]. PTLD is a complex disorder whereby an interplay of factors is involved in facilitating tumorigenesis [17].

The occurrence of PTLD in patients receiving an allogeneic HSCT can reach $24 \%$, depending on the presence of risk factors $[16,18,19]$. The highest incidence of PTLD is seen in the first six months post-transplant, with most cases occurring during the first year post-transplant $[4,6,20]$. Infants are generally at higher risk because they are most often EBV-naïve before transplant [21]. Several clinical risk factors have been associated with EBV infection and PTLD in HSCT, including T-cell depletion of the graft, use of unrelated donors or of two or more HLA-mismatches in related donors, use of anti-lymphocyte serum for prevention or treatment of acute graft-versus-host disease (GvHD) and use of anti-CD3 monoclonal antibodies for acute GvHD [19].

The rapid increase of EBV viral load (EBV-VL) in the blood is a well-documented predictive biomarker of EBV-associated diseases. Following transplantation, regular monitoring of EBV-VL is usually performed for better management of patients who show large spikes in VL [22,23]. A reduction in the intensity of immunosuppression or treatment with the anti-CD20 monoclonal (rituximab) is effective in decreasing EBV-VL to prevent PTLD [24]. In patients receiving HSCT, rituximab use is the more common option [7]. However, both methods for lowering EBV-VL have important disadvantages. Reduction in the intensity of immunosuppression can increase the risk of GvHD [6], while rituximab use in patients who are already immunosuppressed can incur the development of other fatal infections [6]. Rituximab targets CD20-expressing malignant B cells as well as all mature B cells, thus impeding the production of antimicrobial immunoglobulins [6]. There is clearly an important clinical advantage in preventing EBV disease rather than attempting to cure it. Numerous studies have sought to better understand the determinants of EBV infection following allogeneic HSCT. The literature contains numerous important studies that consider one or more risk factors in small to large sample sizes of patients with different characteristics; however, no systematic review is available summarizing the determinants of EBV infection in HSCT. Therefore, the aim of this work was to synthesize, through a systematic review and meta-analysis, the risk factors associated with active EBV infection and with PTLD in HSCT recipients.

\section{Methods}

We conducted, using Medline and EMBASE, a systematic search of all articles on risk factors for active EBV infection (including EBV primary infection as well as EBV reactivation) and PTLD in pediatric and adult recipients of HSCT published in peerreviewed journals between 1946 and 30 June 2020. A non-exhaustive list of concepts and keywords was obtained by referring to articles related to active EBV infection and PTLD; the list was broadened using medical subject heading (MeSH) descriptors in Medline and Emtree in EMBASE. The ovidSP interface was used to search in both databases. The search equations are presented in Table S1. The selection of the articles was done in four steps: (1) title exploration, (2) review of abstracts, (3) review of the articles' contents, and (4) review of the references of selected articles. All selection steps were performed independently by two authors (PE, MZ); in cases of disagreement, a third author (HT) was solicited for a consensual decision. 
For the systematic review, three inclusion conditions were applied: (1) the study population had to be composed of pediatric and/or adult HSCT recipients; (2) risk factors for EBV infection or for PTLD had to be analyzed using univariate and/or multivariate statistical methods; and (3) the paper had to be in English or French. Abstracts, conference papers, congress papers, editorials, guidelines, reviews and case reports were excluded from the systematic review.

Two independent authors (PE and MZ) extracted the following information from the selected articles: authors, publication year, location, study type, post-transplant follow-up duration, transplant type, sample size, population (child or adult, and median or mean age, range or interquartile range), the definition of PTLD or definition of EBV infection, frequency of EBV-VL testing, blood compartment used to measure EBV-VL, and statistical methods used. In addition, for all potential risk factors explored in the studies, point estimates, such as odds ratio (OR), risk ratio (RR), the hazard ratio (HR) and subhazard ratio (SHR), confidence intervals $(\mathrm{CI})$ and $p$-values were extracted when reported. In some cases, the corresponding author was contacted to clarify ambiguities.

The quality of each individual study was independently evaluated by two authors (PE \& MZ) using a modified version of the Effective Public Health Practice Project (EPHPP) quality assessment tool for quantitative studies $[25,26]$. The quality assessment was based on the following components: selection bias, study design, confounders and data collection methods; it was rated as strong, moderate or weak (from high-quality to low-quality) according to the definition presented in Table S2a.

Finally, risk factors explored in these studies were described by providing the total number of studies showing a statistically significant association contrasted to the total number of studies investigating the risk factor.

The data reported made it possible to perform a meta-analysis solely to measure the association between the use of anti-thymocyte globulin (ATG) and two outcomes: posttransplant EBV infection and PTLD. Studies using multivariate analysis were considered for the meta-analysis except for the study by Liu et al. [27] because only the $p$-value was reported (not the measure of association). Since post-transplant EBV infection is not a rare event in this population, to obtain pooled estimates, results from studies that reported adjusted HR or SHR were combined separately from those that reported adjusted OR. This distinction was not made for PTLD, which is a relatively less frequent event. Adjusted estimates were combined using the inverse variance method with the fixed-effect model or random-effect model. The choice between these two models was guided by the value of statistic I, which revealed the proportion of the total variance observed due to a real difference in the measures of effects between studies. The fixed-effect model was used when $\mathrm{I}^{2}<25 \%$ and the random-effect model when $\mathrm{I}^{2} \geq 25 \%[28,29]$. We also performed a sensitivity analysis to assess the contribution of each study to the pooled estimate. To this end, the pooled estimate was recalculated, each time excluding only one of the studies considered [30]. The analysis was performed with software $\mathrm{R}$ version 3.6.1.

\section{Results}

In total, 3362 titles were identified in the research bases, 1883 in EMBASE and 1479 in Medline. Once duplicates and papers with exclusion criteria were removed, 77 articles $[4,16,23,24,27,31-102]$ fulfilled the inclusion criteria for our systematic review (62 for EBV and 22 for PTLD). Among the 22 articles selected for PTLD, seven were also retained for EBV. Detailed information on the selection procedure is provided in the flow diagram (Figure 1). Among the 62 articles included to analyze risk factors for post-transplant EBV infection, two relate exactly to the same patient cohort (Bogunia-Kubik et al. [36] and Bogunia-Kubik et al. [35]) and 11 relate to non-disjoint samples (include some of the same patients) (Cesaro et al. [41] and Cesaro et al. [42]; Liu et al. [74] and Liu et al. [27]; Xuan et al. [99] and Liu et al. [74]; Liu et al. [75] and Liu et al. [73]; Wang et al. [97] and Ru et al. [86]; Zhou et al. [102] and Zhou et al. [101]). However, none of these studies but one [101] were excluded from the qualitative synthesis for duplication because the risk 
factors explored were different. The study by Zhou et al. [102] was excluded because all variables in this paper were explored using univariate analysis and were considered in the study by Zhou et al. [101] using multivariate analysis. With respect to the analysis of PTLD risk factors, the studies by Sundin et al. [103] and Omar et al. [81] were discarded because Uhlin et al. [94] explored the same factors and sample population as these two studies. Hoegh-Petersen et al. [60] and Kalra et al. [67] used non-disjoint samples. However, these two studies were retained in the review because the risk factors explored were not completely identical. For the same risk factors explored in both studies, those from Kalra et al. [67] were retained as the analyses were done on a larger sample. In addition, the Ali et al. [31] and Althubaiti et al. [32] studies were carried out with non-disjoint samples, but both were retained because different variables were explored.

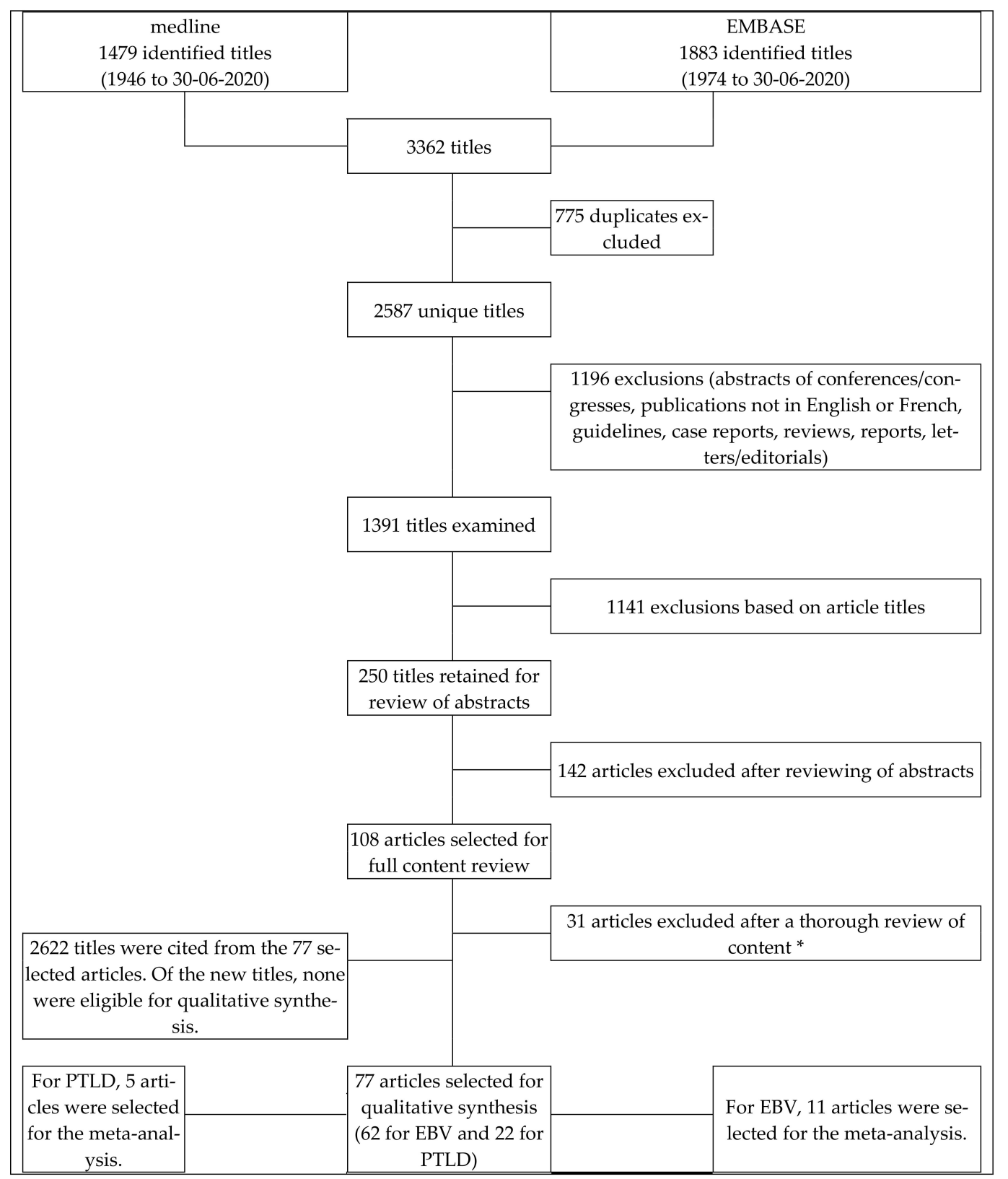

Figure 1. Search strategy flowchart. * The reasons for exclusion of these articles were as follows: Two articles were excluded because their sample is a subset of the sample from two other articles. There was no univariate or multivariate statistical analysis for the identification of risk factors for post-transplant active EBV infection or PTLD in 26 articles and in three articles. EBV post-transplant infection was combined with other viral infections in a single variable. 
Characteristics of the selected studies are described in Table 1; more details are provided in Table S3. Briefly, among the 77 studies, seven were conducted in France, seven in Italy, six in Poland, one in Belgium, three in Spain, six in the United Kingdom, one in Finland, five in the United States, three in Japan, 16 in China, two in Korea, one in Russia, five in Canada, three in Sweden, one in Turkey, three in Germany, two in the Netherlands, one in Greece, one in Portugal and three were multi-national. Twenty-three studies were prospective, 51 were retrospective, two were case-control studies and one was a randomized control trial. The sample size ranged from 26 to 64,539 HSCT recipients (Figure 2). It is noteworthy that most studies were performed with pooled pediatric and adult populations $(n=41)$, while 19 included only children and 17 only adults.
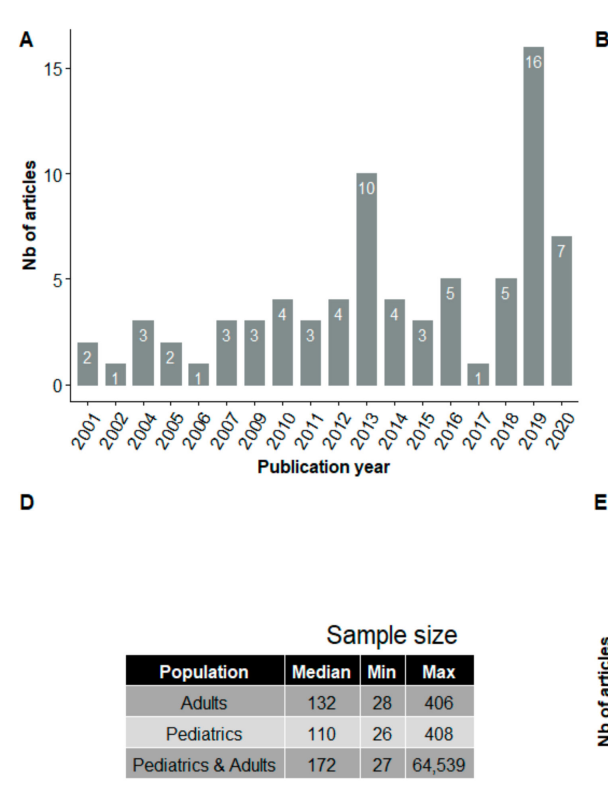

D
B

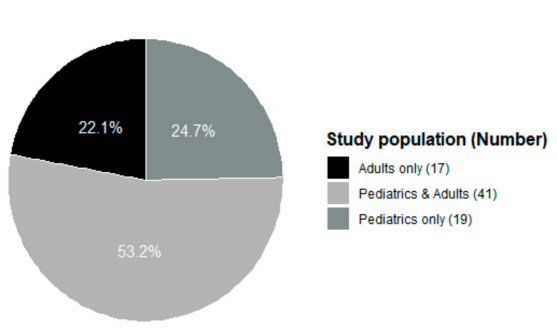

C

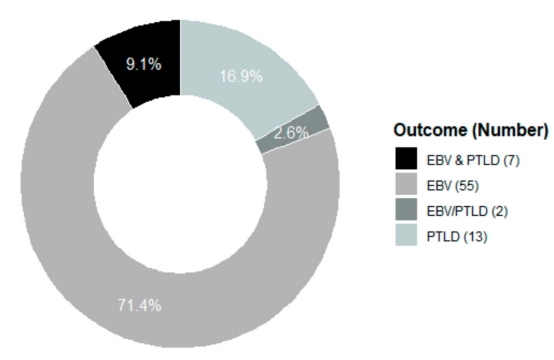

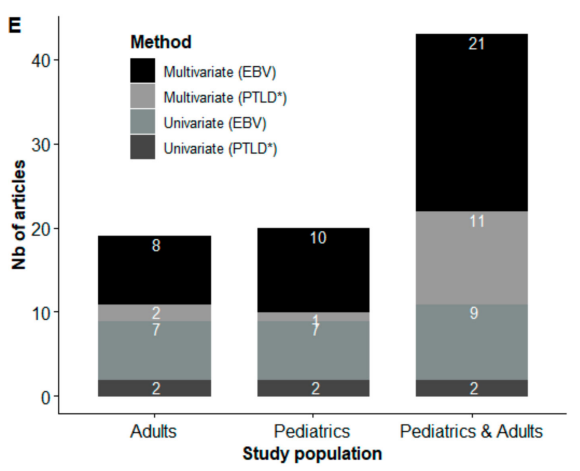

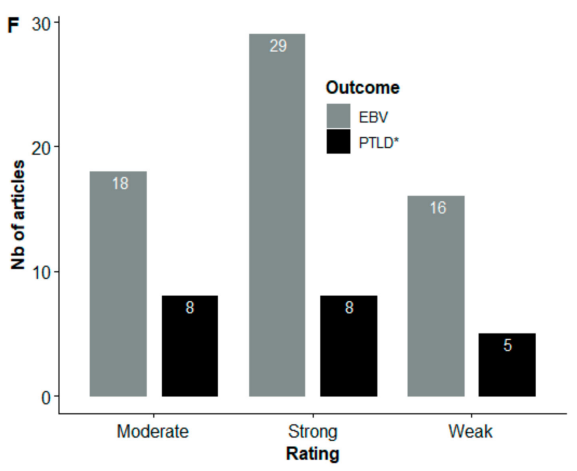

Figure 2. Summary of some characteristics of the studies included in the systematic review. (A) Number of studies by year of publication; (B) Proportion (number) of studies by type of population; (C) Proportion (number) of studies according to the type of outcome; (D) Descriptive statistics on sample size by type of population; (E) Number of studies according to the type of statistical analysis carried out, the type of population and the outcome; (F) Number of studies by type of outcome and by quality level. EBV and PTLD: The two outcomes were studied separately in the same article; EBV/PTLD: The two outcomes were combined into one. * Studies with the outcome PTLD/EBV and the studies with outcome PTLD were considered together. 
Table 1. Characteristics of the 77 studies included in the systematic review.

\begin{tabular}{|c|c|c|c|c|c|c|c|c|}
\hline First Author, Year & Country & Study Type & $\begin{array}{c}\text { Study } \\
\text { Population }\end{array}$ & $\begin{array}{l}\text { Sample } \\
\text { Size }\end{array}$ & Outcome & $\begin{array}{c}\text { Median (Range) } \\
\text { of Follow-Up }\end{array}$ & $\begin{array}{l}\text { Statistical } \\
\text { Analysis }\end{array}$ & $\begin{array}{l}\text { Overall Rating } \\
\text { (Table S2) }\end{array}$ \\
\hline Ali, 2019 [31] & Canada & Retrospective & $\mathrm{P}$ & 408 & PTLD & NR & Univariate & Weak \\
\hline Althubaiti, 2019 [32] & Canada & Retrospective & $\mathrm{P}$ & 26 & PTLD & NR & Univariate & Weak \\
\hline Atay, 2018 [33] & Turkey & Retrospective & $\mathrm{P}$ & 171 & $\mathrm{EBV}^{ \pm}$ & 14 months & Univariate & Weak \\
\hline Auger, 2014 [34] & France & Retrospective & A & 190 & EBV & $\begin{array}{c}36.6 \text { months } \\
\text { (95\% IC } \\
31.5-45.7)\end{array}$ & Multivariate & Weak \\
\hline $\begin{array}{c}\text { Bogunia-Kubik, } 2007 \\
{[35]}\end{array}$ & Poland & Retrospective & $\mathrm{P}$ and $\mathrm{A}$ & 92 & EBV & NR & Multivariate & Strong \\
\hline $\begin{array}{c}\text { Bogunia-Kubik, } 2005 \\
{[36]}\end{array}$ & Poland & Retrospective & $\mathrm{P}$ and $\mathrm{A}$ & 83 & EBV & NR & Multivariate & Strong \\
\hline Bordon, 2012 [37] & Belgium & Retrospective & $\mathrm{P}$ & 80 & EBV & NR & Multivariate & Moderate \\
\hline Brunstein, 2006 [38] & USA & $\begin{array}{l}\text { Multicenter } \\
\text { retrospective }\end{array}$ & $\mathrm{P}$ and $\mathrm{A}$ & 335 & EBV/PTLD & $\begin{array}{c}1.2 \text { (77 days-9.2 } \\
\text { years) }\end{array}$ & Multivariate & Moderate \\
\hline Burns, 2016 [39] & $\begin{array}{l}\text { United } \\
\text { Kingdom }\end{array}$ & Retrospective & $\mathrm{P}$ and $\mathrm{A}$ & 186 & EBV & 28 months & Multivariate & Strong \\
\hline Buyck, 2009 [40] & $\begin{array}{c}\text { United } \\
\text { Kingdom }\end{array}$ & Retrospective & $\mathrm{P}$ and $\mathrm{A}$ & 87 & PTLD & NR & Multivariate & Moderate \\
\hline Carpenter, 2010 [23] & $\begin{array}{l}\text { United } \\
\text { Kingdom }\end{array}$ & Retrospective & $\mathrm{P}$ and $\mathrm{A}$ & $111^{\mathrm{a}}$ & EBV & 2.4 years & Multivariate & Strong \\
\hline Cesaro, 2004 [41] & Italy & Retrospective & $\mathrm{P}$ & $79^{b}$ & EBV & NR & Multivariate & Moderate \\
\hline Cesaro, 2010 [42] & Italy & Retrospective & $\mathrm{P}$ & 89 & EBV & NR & Univariate & Weak \\
\hline Chiereghin, 2016 [43] & Italy & Prospective & $\mathrm{P}$ & 28 & EBV & 7.1 months & Univariate & Weak \\
\hline Chiereghin, 2019 [44] & Italy & Prospective & $\mathrm{P}$ and $\mathrm{A}$ & 51 & EBV & NR & Univariate & Weak \\
\hline Christopeit, 2013 [45] & USA & Retrospective & $\mathrm{A}$ & $28^{c}$ & EBV & NR & Multivariate & Moderate \\
\hline Cohen, 2005 [46] & $\begin{array}{l}\text { United } \\
\text { Kingdom }\end{array}$ & Prospective & $\mathrm{P}$ & 128 & EBV & NR & Multivariate & Moderate \\
\hline Cohen, 2005 [46] & $\begin{array}{l}\text { United } \\
\text { Kingdom }\end{array}$ & Prospective & $\mathrm{P}$ & 128 & PTLD & NR & Multivariate & Moderate \\
\hline Comoli, 2007 [47] & Italy & Prospective & $\mathrm{P}$ and $\mathrm{A}$ & 27 & EBV & 23 months & Univariate & Weak \\
\hline Czyżewski, 2019 [48] & Poland & $\begin{array}{l}\text { Retrospective } \\
\text { multicenter } \\
\text { study }\end{array}$ & $\mathrm{P}$ and $\mathrm{A}$ & 1569 & EBV & NR & Univariate & Weak \\
\hline D'Aveni, 2011 [49] & France & Retrospective & $\mathrm{P}$ and $\mathrm{A}$ & $40^{\mathrm{d}}$ & EBV & NR & Univariate & Weak \\
\hline Dumas, 2013 [50] & France & $\begin{array}{l}\text { Multicenter } \\
\text { retrospective }\end{array}$ & $\mathrm{P}$ and $\mathrm{A}$ & 175 & EBV & NR & Multivariate & Moderate \\
\hline Düver, 2020 [51] & Germany & Retrospective & $\mathrm{P}$ & 107 & EBV & $\begin{array}{l}365 \text { (range: } \\
22-365 \text { ) days }\end{array}$ & Multivariate & Strong \\
\hline Elmahdi, 2016 [52] & Japan & Retrospective & $\mathrm{P}$ & 37 & EBV & NR & Multivariate & Moderate \\
\hline Fan, 2016 [53] & China & Retrospective & $\mathrm{P}$ and $\mathrm{A}$ & $44^{\mathrm{e}}$ & $\mathrm{EBV}^{ \pm}$ & NR & Multivariate & Moderate \\
\hline Figgins, 2019 [54] & USA & Retrospective & A & 123 & EBV & $\begin{array}{c}12.8 \text { (range: } \\
1.0-23.1) \text { months }\end{array}$ & Univariate & Weak \\
\hline Fujimoto, 2019 [55] & Japan & $\begin{array}{l}\text { Multicenter } \\
\text { retrospective }\end{array}$ & $\mathrm{P}$ and $\mathrm{A}$ & 64,539 & PTLD & NR & Multivariate & Strong \\
\hline Gao, 2019 [56] & China & Retrospective & $\mathrm{P}$ and $\mathrm{A}$ & 200 & EBV & NR & Multivariate & Strong \\
\hline Gao, 2019 [56] & China & Retrospective & $\mathrm{P}$ and $\mathrm{A}$ & 200 & PTLD & NR & Multivariate & Strong \\
\hline $\begin{array}{c}\text { Garcia-Cadenas, } 2015 \\
\text { [57] }\end{array}$ & Spain & Prospective & A & 93 & EBV & NR & Multivariate & Strong \\
\hline $\begin{array}{c}\text { Garcia-Cadenas, } 2015 \\
\text { [57] }\end{array}$ & Spain & Prospective & A & 93 & PTLD & NR & Multivariate & Strong \\
\hline Han, 2014 [58] & Korea & Retrospective & $\mathrm{P}$ & 248 & EBV & NR & Univariate & Weak \\
\hline Hiwarkar, 2013 [59] & $\begin{array}{l}\text { United } \\
\text { Kingdom }\end{array}$ & Retrospective & $\mathrm{P}$ & 278 & EBV & NR & Multivariate & Moderate \\
\hline $\begin{array}{c}\text { Hoegh-Petersen, } 2011 \\
\text { [60] }\end{array}$ & Canada & Retrospective & A & 307 & PTLD & $\begin{array}{l}375 \text { (28-1727) } \\
\text { days }\end{array}$ & Univariate & Weak \\
\hline Hoshino, 2001 [61] & Japan & Prospective & $\mathrm{P}$ and $\mathrm{A}$ & 38 & EBV & NR & Univariate & Weak \\
\hline Islam, 2010 [62] & $\begin{array}{l}\text { United } \\
\text { Kingdom }\end{array}$ & Retrospective & $\mathrm{P}$ and $\mathrm{A}$ & 83 & EBV & $\begin{array}{c}4.2(0.9-8.1) \\
\text { years }\end{array}$ & Univariate & Weak \\
\hline Issa, 2019 [63] & USA & Retrospective & $\mathrm{A}$ & 357 & EBV & NR & Univariate & Weak \\
\hline Kutnik, 2019 [64] & Poland & Retrospective & $\mathrm{P}$ & 198 & EBV & 12 months & Univariate & Weak \\
\hline Jaskula, 2010 [65] & Poland & Prospective & $\mathrm{P}$ and $\mathrm{A}$ & 102 & EBV & NR & Multivariate & Moderate \\
\hline Juvonen, 2007 [66] & Finland & Retrospective & $\mathrm{A}$ & 406 & EBV & NR & Multivariate & Strong \\
\hline Kalra, 2018 [67] & Canada & Retrospective & $\mathrm{P}$ and $\mathrm{A}$ & 554 & PTLD & 509 days & Multivariate & Strong \\
\hline
\end{tabular}


Table 1. Cont.

\begin{tabular}{|c|c|c|c|c|c|c|c|c|}
\hline First Author, Year & Country & Study Type & $\begin{array}{c}\text { Study } \\
\text { Population }\end{array}$ & $\begin{array}{c}\text { Sample } \\
\text { Size }\end{array}$ & Outcome & $\begin{array}{l}\text { Median (Range) } \\
\text { of Follow-Up }\end{array}$ & $\begin{array}{l}\text { Statistical } \\
\text { Analysis }\end{array}$ & $\begin{array}{c}\text { Overall Rating } \\
\text { (Table S2) }\end{array}$ \\
\hline $\begin{array}{c}\text { Kullberg-Lindh, } 2015 \\
\text { [68] }\end{array}$ & Sweden & Retrospective & $\mathrm{P}$ & 47 & EBV & NR & Multivariate & Strong \\
\hline Laberko, 2017 [69] & Russia & Retrospective & $\mathrm{P}$ & 182 & EBV & 27 months & Multivariate & Strong \\
\hline Landgren, 2009 [70] & CIBMTR & $\begin{array}{l}\text { Multicenter } \\
\text { retrospective }\end{array}$ & $\mathrm{P}$ and $\mathrm{A}$ & 26,901 & PTLD & $>12$ months & Multivariate & Strong \\
\hline $\mathrm{Li}, 2018[71]$ & China & Retrospective & $\mathrm{P}$ & 62 & $\mathrm{EBV}^{\perp}$ & $\begin{array}{l}32.5(0.5-132) \\
\text { months }\end{array}$ & Univariate & Weak \\
\hline Lin, 2019 [72] & China & $\begin{array}{l}\text { Multicenter } \\
\text { randomized } \\
\text { study }\end{array}$ & $\mathrm{P}$ and $\mathrm{A}$ & 408 & EBV & NR & Multivariate & Strong \\
\hline Liu, 2020 [73] & China & Prospective & A & 170 & EBV & NR & Multivariate & Strong \\
\hline Liu, 2020 [73] & China & Prospective & A & 170 & PTLD & NR & Univariate & Weak \\
\hline Liu, 2013 [74] & China & Prospective & $\mathrm{P}$ and $\mathrm{A}$ & $251^{\mathrm{f}}$ & EBV & $327 \begin{array}{l}(27-1408) \\
\text { days }\end{array}$ & Multivariate & Strong \\
\hline Liu, 2013 [27] & China & Prospective & $\mathrm{P}$ and $\mathrm{A}$ & 172 & EBV & $\begin{array}{l}495\left(\begin{array}{l}(45-1158) \\
\text { days }\end{array}\right. \\
\end{array}$ & Multivariate & Strong \\
\hline Liu, 2013 [27] & China & Prospective & $\mathrm{P}$ and $\mathrm{A}$ & 172 & PTLD & 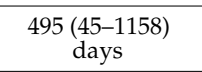 & Multivariate & Strong \\
\hline Liu, 2018 [75] & China & Prospective & A & 132 & EBV & NR & Univariate $\ddagger$ & Strong \\
\hline $\begin{array}{c}\text { Marinho-Dias, } \\
2019 \text { [76] }\end{array}$ & Portugal & Prospective & $\mathrm{P}$ and $\mathrm{A}$ & 40 & EBV & $>120$ days & Multivariate & Strong \\
\hline Meijer, 2004 [77] & Netherlands & Prospective & A & $78^{g}$ & EBV & (6-32) months & Univariate & Weak \\
\hline Mountjoy, 2020 [78] & USA & Retrospective & A & 209 & EBV & $\begin{array}{c}\text { Non-ATG group } \\
677 \text { (7-3147) } \\
\text { days } \\
\text { ATG group } \\
504 \text { (33-2156) } \\
\text { days }\end{array}$ & Univariate & Weak \\
\hline Neumann, 2018 [79] & Germany & Case-control & A & 44 & $\mathrm{EBV}^{\perp}$ & $\mathrm{NR}$ & Univariate ${ }^{\S}$ & Strong \\
\hline Nowak, 2019 [80] & Poland & Retrospective & $\mathrm{P}$ and $\mathrm{A}$ & 239 & EBV & $\begin{array}{l}2.1(0.2-67.8) \\
\text { months }\end{array}$ & Univariate & Weak \\
\hline Omar, 2009 [81] & Sweden & Prospective & $\mathrm{P}$ and $\mathrm{A}$ & 131 & EBV & NR & Multivariate & Moderate \\
\hline Pagliuca, 2019 [82] & France & Retrospective & $\mathrm{P}$ and $\mathrm{A}$ & 208 & PTLD & $\begin{array}{c}47.33 \\
\text { (3.18-126.20) } \\
\text { months }\end{array}$ & Multivariate & Strong \\
\hline Park, 2020 [83] & Korea & Retrospective & $\mathrm{P}$ and $\mathrm{A}$ & 114 & EBV & NR & Univariate & Weak \\
\hline Patriarca, 2013 [4] & Italy & Prospective & $\mathrm{A}$ & $100^{h}$ & EBV & 7 (2-36) months & Multivariate & Strong \\
\hline Peric, 2012 [84] & France & Retrospective & A & 33 & EBV & $\begin{array}{c}468 \text { (92-1277) } \\
\text { days }\end{array}$ & Univariate & Weak \\
\hline Peric, 2011 [85] & France & Retrospective & A & 175 & EBV & $\begin{array}{l}655 \text { (92-1542) } \\
\text { days }\end{array}$ & Multivariate & Strong \\
\hline $\mathrm{Ru}, 2020[86]$ & China & Retrospective & $\mathrm{P}$ and $\mathrm{A}$ & 890 & EBV & NR & Multivariate & Strong \\
\hline Rustia, 2016 [87] & USA & Retrospective & $\mathrm{P}$ & 140 & EBV & NR & Univariate & Weak \\
\hline Sanz, 2014 [88] & Spain & Retrospective & $\mathrm{P}$ and $\mathrm{A}$ & 288 & EBV & $>6$ months & Multivariate & Strong \\
\hline Sanz, 2014 [88] & Spain & Retrospective & $\mathrm{P}$ and $\mathrm{A}$ & 288 & PTLD & $>6$ months & Multivariate & Strong \\
\hline $\begin{array}{c}\text { Sirvent-von } \\
\text { Bueltzingsloewen, } \\
2002 \text { [89] }\end{array}$ & France & $\begin{array}{l}\text { Multicenter } \\
\text { prospective }\end{array}$ & $\mathrm{P}$ and $\mathrm{A}$ & $85^{\mathrm{i}}$ & EBV & $\begin{array}{l}306(26-867) \\
\text { days }\end{array}$ & Multivariate & Strong \\
\hline Styczynski, 2013 [90] & EBMT & $\begin{array}{c}\text { Multicenter } \\
\text { retrospective }\end{array}$ & $\mathrm{P}$ and $\mathrm{A}$ & 4466 & PTLD & NR & Univariate & Weak \\
\hline $\begin{array}{c}\text { Torre-Cisneros, } 2004 \\
\text { [91] }\end{array}$ & Spain & Prospective & $\mathrm{P}$ and $\mathrm{A}$ & $100^{j}$ & EBV & NR & Multivariate & Moderate \\
\hline Trottier, 2012 [92] & Canada & Retrospective & $\mathrm{P}$ & 238 & EBV & NR & Multivariate & Moderate \\
\hline Tsoumakas, 2019 [93] & Greece & Prospective & $\mathrm{P}$ & 110 & EBV & $\geq 1$ year & Multivariate & Strong \\
\hline Uhlin, 2014 [94] & Sweden & Retrospective & $\mathrm{P}$ and $\mathrm{A}$ & 1021 & PTLD & NR & Multivariate & Strong \\
\hline $\begin{array}{c}\text { Van der Velden, } 2013 \\
\text { [95] }\end{array}$ & Netherlands & Retrospective & A & 273 & EBV/PTLD & $\geq 6$ months & Multivariate & Moderate \\
\hline Van Esser, 2001 [96] & $\begin{array}{l}\text { Italy, Germany, } \\
\text { Netherlands }\end{array}$ & $\begin{array}{l}\text { Multicenter } \\
\text { prospective }\end{array}$ & $\mathrm{P}$ and $\mathrm{A}$ & 152 & EBV & NR & Multivariate & Strong \\
\hline Van Esser, 2001 [96] & $\begin{array}{l}\text { Italy, Germany, } \\
\text { Netherlands }\end{array}$ & $\begin{array}{l}\text { Multicenter } \\
\text { prospective }\end{array}$ & $\mathrm{P}$ and $\mathrm{A}$ & 152 & PTLD & NR & Multivariate & Strong \\
\hline Wang, 2019 [97] & China & Retrospective & $\mathrm{P}$ and $\mathrm{A}$ & 186 & EBV & NR & Multivariate & Strong \\
\hline Xu, 2015 [98] & China & Case-control & $\mathrm{P}$ and $\mathrm{A}$ & 180 & PTLD & NR & Multivariate & Strong \\
\hline Xuan, 2012 [99] & China & Prospective & $\mathrm{P}$ and $\mathrm{A}$ & 185 & EBV & 319 (27-1194) & Multivariate & Strong \\
\hline
\end{tabular}


Table 1. Cont.

\begin{tabular}{|c|c|c|c|c|c|c|c|c|}
\hline First Author, Year & Country & Study Type & $\begin{array}{c}\text { Study } \\
\text { Population }\end{array}$ & $\underset{\text { Size }}{\text { Sample }}$ & Outcome & $\begin{array}{c}\text { Median (Range) } \\
\text { of Follow-Up }\end{array}$ & $\begin{array}{l}\text { Statistical } \\
\text { Analysis }\end{array}$ & $\begin{array}{c}\text { Overall Rating } \\
\text { (Table S2) }\end{array}$ \\
\hline Xuan, 2013 [16] & China & Prospective & $\mathrm{P}$ and $\mathrm{A}$ & 263 & PTLD & $\begin{array}{l}374(27-1554) \\
\text { days }\end{array}$ & Multivariate & Strong \\
\hline Yu, 2019 [100] & China & Prospective & $\mathrm{P}$ and $\mathrm{A}$ & 90 & EBV & NR & Multivariate & Moderate \\
\hline Zallio, 2013 [24] & Italy & Prospective & $\mathrm{A}$ & 100 & EBV & NR & Multivariate & Moderate \\
\hline Zhou, 2020 [101] & China & Retrospective & $\mathrm{P}$ and $\mathrm{A}$ & 131 & EBV & $\begin{array}{l}59.2 \text { (range: } \\
\text { 2.03-113.8) } \\
\text { months }\end{array}$ & Multivariate & Strong \\
\hline Zhou, 2020 [102] & China & Retrospective & $P$ and $A$ & 160 & PTLD & $\begin{array}{c}64.7 \text { (range: } \\
2.03-113.8 \text { ) } \\
\text { months }\end{array}$ & Univariate & Weak \\
\hline
\end{tabular}

a Alemtuzumab was considered in the conditioning protocol of all patients, and only patients with at least 6 months of follow-up were considered. ${ }^{b}$ Almost all patients received the standard conditioning regimen. ${ }^{c}$ All of these patients had positive EBV serology, survived beyond 40 days and received cyclosporine beyond 30 days post-transplant. ${ }^{\mathrm{d}}$ Of the 40 patients, five were excluded: three because of related early transplant mortality and two dues to relapse before 60 days of follow-up. ${ }^{\mathrm{e}}$ All patients in the study had positive CMV serology and negative PCR tests for herpesviruses (EBV, CMV, and HHV-6) one week after transplantation. ${ }^{\mathrm{f}}$ All patients had a negative EBV PCR test at the start of follow-up. ${ }^{g}$ All except 1 (receiving bone marrow) received a peripheral blood stem cell graft. ${ }^{\mathrm{h}}$ All patients had a follow-up duration $>30$ days post-transplant. ${ }^{i}$ Five patients with post-transplant lymphoproliferative syndrome were excluded. Analysis of risk factors for EBV reactivation involved 80 patients. ${ }^{j}$ All patients had positive EBV serology before transplantation. $\S$ The individuals were matched according to the variables age, diagnosis, and conditioning regimen. $\ddagger$ Chi 2 test and Mann-Whitney U test were used to verify that the distributions of potential confounding factors were not significantly different. ${ }^{\perp}$ The outcome has not been explicitly defined. Abbreviation: ATG: anti-thymocyte globulin; CIBMTR: Center for International Blood and Marrow Transplant Research; EBV: Epstein-Barr virus; EMBT: European Group for Blood and Marrow Transplantation; NR: not reported; P: pediatrics; P and A: pediatrics and adults; PTLD: post-transplant lymphoproliferative disease.

The definition of post-transplant EBV infection and the diagnostic criteria for PTLD differed among studies. Active post-transplant EBV infection was diagnosed when the EBV-VL in blood, determined using a PCR test, was above a given threshold. In some cases, thresholds were not readily comparable because there was no direct conversion between the units of measurement used. In two studies [45,91], active EBV infection was defined as a reactivation event because all patients showed positive EBV serology when the follow-up period started. In other studies, no distinction was made between primary infection and reactivation: both were considered active EBV infection. There was also some variability between studies with respect to the frequency of PCR testing, but it was performed weekly in most studies during the early post-transplant period. The type of specimen tested by PCR varied, with peripheral blood in 19 studies, plasma in 11 studies, serum in five studies, serum or plasma in one study, whole blood in 13 studies, peripheral blood or whole blood in two studies, and whole blood and plasma in one study; 10 studies provided no information on specimen type. The method used to diagnose PTLD was not detailed in one study. The length of follow-up was an important source of variation between studies; in some cases the follow-up period was not reported [31,32,34,40,46,48,52,55,59,61,63,73,81,83,86,90,94,98,100].

Various statistical methods were used. Logistic regression was used in 13 studies, Cox model in 22, survival analysis using the log-rank test in one, multiple linear regression in two, Fine and Gray competitive risk model in 10 and Poisson regression for grouped survival data in one. Among the 28 studies employing univariate analysis, the statistical method was not explicitly reported in one study; one study used univariate logistic regression, another used the univariate Cox model, another used time-dependent landmark, while other studies used at least one of the following tests: Log-rank test, Gray's test, Chi 2 test, Wilcoxon nonparametric test, Kruskal-Wallis test, Fisher's exact test, Mann-Whitney test or Wald test. Among the 49 studies in which a multivariate analysis was performed, the criteria for selecting variables for the multivariate model were explicitly indicated in 20. Variables with a $p$-value $<0.1$ in univariate analysis were retained for multivariate analysis in eight studies, a $p$-value $<0.2$ in three, a $p$-value $<0.3$ in one, a $p$-value $<0.05$ in one; a $p$-value $<0.05$ was used for the multivariate analysis in three studies. In four studies, the investigators used a $p$-value $<0.1$ in the univariate analysis combined with a $p$-value $<0.05$ in multivariate analysis. Altogether, 52 studies were considered as properly adjusted for confounding bias. 
Table S2b reports the quality assessment of the 74 articles included in the review according to the outcome. Regarding post-transplant EBV infection, $27(42.9 \%)$ were rated "strong", 15 (23.8\%) "moderate" and 21 (33.3\%) "weak". For PTLD, 12 (57.1\%) were rated "strong", three (14.3\%) "moderate" and six (28.6\%) "weak". The lack of information on retention and potential for selection bias, as well as the absence of control for potential confounding bias, were the main contributors to the lower overall rating of articles. It is important to note that the absence of control for confusion in several articles could be justified by the fact that their main focus did not involve analysis of factors associated with either post-transplant EBV infection or PTLD.

Table S4 provides a detailed list of the risk factors for post-transplant EBV infection and for PTLD explored in the 77 included studies with a description, when possible, of the measures of association and CI and/or $p$-value. Figure 3 presents, for every individual risk factor, the total number of studies that investigated the risk factor contrasted to the number that showed a statistically significant association. Table 2 presents a summary of the risk factors (with measures of association) for post-transplant EBV infection and for PTLD that were analyzed in studies using multivariate analysis. The presence of GvHD, use of ATG and type of conditioning regimen were the three risk factors most frequently associated with EBV infection and PTLD.

A

(zd) Graft source (BM, PBSC, CB) -

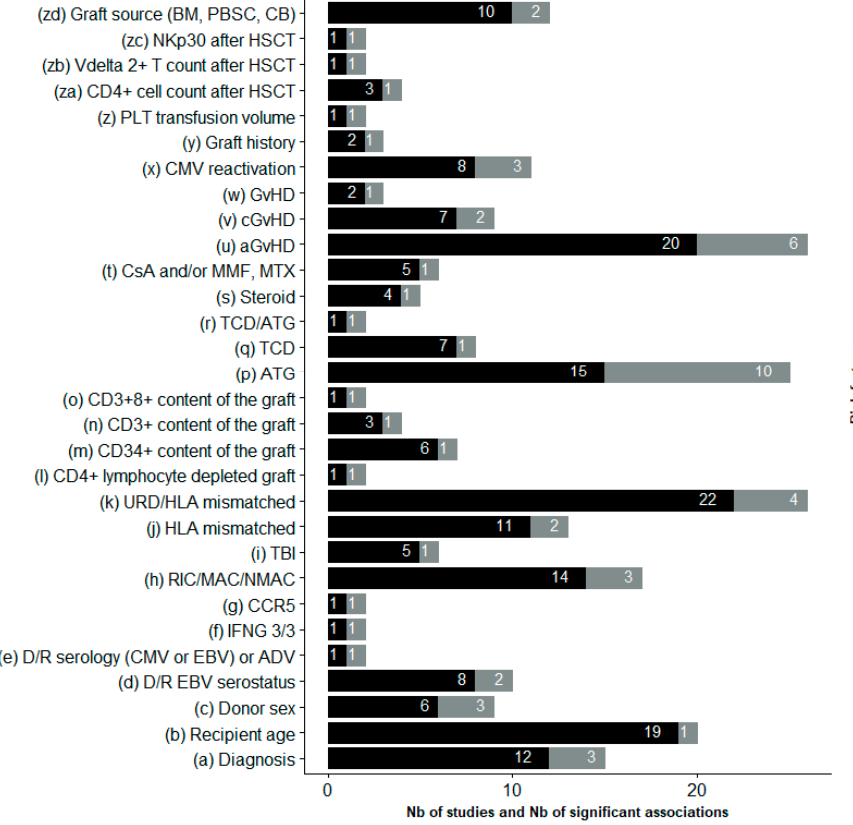

(ww) Fever at onset of EBV infection (w) Fludarabine-

(t) Diagnosis (ss) D/R Sex (rr) IgM count after HSCT (qq) $\mathrm{CD} 8+$ cell count after HSCT (pp) Graft history (oo) CMV reactivation (nn) aGvHD or GvHD (mm) cGvHD (II) aGvHD (kk) TCD (ii) $\mathrm{Nb}$ of prior courses of ATG (ii) ATG (hh) Splenectomy (gg) MSC treatment (ff) URD/HLA mismatched (ee) HLA mismatched (dd) RIC/MAC/NMAC (cc) D/R EBV serostatus (bb) Recipient age

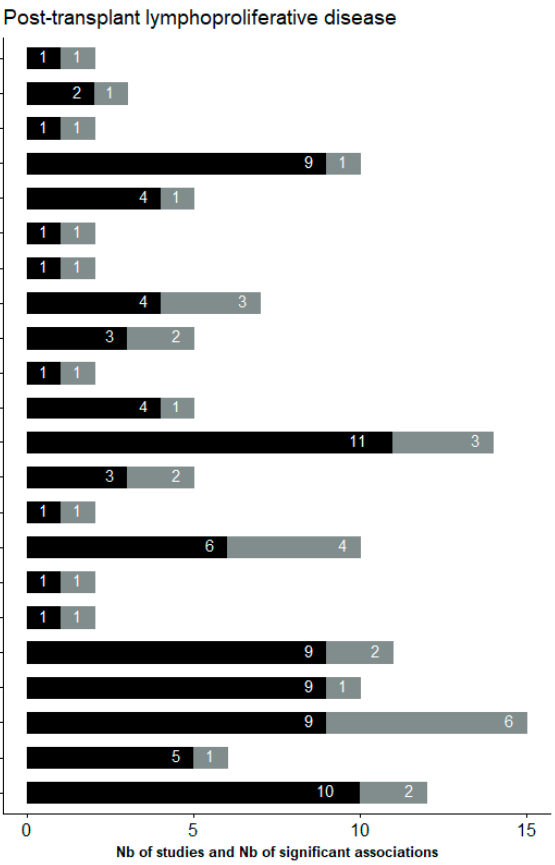

Figure 3. Summary of risk factors for post-transplant EBV infection (A) and for PTLD (B) explored in the studies that controlled for confounding. Abbreviations: ADV: adenovirus; aGvHD: acute graft-versus-host disease; ATG: anti-thymocyte globulin; BM: bone marrow; CB: cord blood; CCR5: C-C chemokine receptor 5; cGvHD: chronic graft-versus-host disease; CMV: cytomegalovirus; CsA: cyclosporine A; D/R: donor/recipient; GvHD: graft-versus-host disease; HLA: human leukocyte antigen; HSCT: hematopoietic stem cell transplantation; IFNG: interferon- $\gamma$ gene; MAC: myeloablative conditioning; MMF: mycophenolate mofetil; MSC: mesenchymal stromal cells; MTX: methotrexate; NK: natural killer cells; NMAC: nonmyeloablative conditioning; PBSC: peripheral blood stem cells; PLT: platelets; RIC: reduced-intensity conditioning; TBI: total body irradiation; TCD: T-cell depletion; URD: unrelated donor. 
Table 2. Summary of risk factors for post-transplant EBV infection and for PTLD in the studies using multivariate analysis.

\begin{tabular}{|c|c|c|c|c|}
\hline First Author, Year & Outcome & Study Population & Risk Factors & Estimate $(95 \% \mathrm{CI}) ; p$-Value * \\
\hline & \multicolumn{4}{|c|}{ Recipient age } \\
\hline Bogunia-Kubik, 2007 [35] & EBV & $\mathrm{P}$ and $\mathrm{A}$ & $>$ vs. $\leq 25$ years & $\mathrm{OR}=1.54(1.136-2.703) ; p=0.034$ \\
\hline $\mathrm{Ru}, 2020[86]$ & EBV & $\mathrm{P}$ and $\mathrm{A}$ & $<30$ vs. $\geq 30$ years & $\mathrm{HR}=1.041(0.763-1.420) ; p=0.799$ \\
\hline Düver, 2020 [51] & EBV & $\mathrm{P}$ & Age (continuous) & $\mathrm{OR}=1.08(1.00-1.17) ; p=0.057$ \\
\hline Kullberg-Lindh, 2011 [68] & EBV & $\mathrm{P}$ & Continuous & Slope $=-0.06 ; p=0.09$ \\
\hline Gao, 2019 [56] & PTLD & $\mathrm{P}$ and $\mathrm{A}$ & $\geq 40$ vs. $<40$ years & $\mathrm{HR}=0.4(0.2-0.9) ; p=0.032$ \\
\hline \multirow[t]{2}{*}{ Landgren, 2009 [70] } & PTLD & $\mathrm{P}$ and $\mathrm{A}$ & $\geq 50$ years & $\mathrm{RR}=5.1(2.8-8.7)$ \\
\hline & \multicolumn{4}{|c|}{ Diagnosis } \\
\hline \multirow{6}{*}{ Burns, 2016 [39] } & \multirow{6}{*}{ EBV } & \multirow{6}{*}{$\mathrm{P}$ and $\mathrm{A}$} & NHL vs. AML/MDS & $\mathrm{HR}=0.18(0.05-0.57) ; p=0.004$ \\
\hline & & & ALL vs. AML/MDS & $\mathrm{HR}=0.89(0.45-1.75) ; p=0.734$ \\
\hline & & & HL vs. AML/MDS & $\mathrm{HR}=1.63(0.64-4.16) ; p=0.308$ \\
\hline & & & CLL vs. AML/MDS & $\mathrm{HR}=0.87(0.41-1.85) ; p=0.724$ \\
\hline & & & MPD vs. AML/MDS & $\mathrm{HR}=0.95(0.43-2.11) ; p=0.907$ \\
\hline & & & Other vs. AML/MDS & $\mathrm{HR}=3.01(0.94-9.65) ; P=0.063$ \\
\hline \multirow{5}{*}{ Carpenter, 2010 [23] } & \multirow{5}{*}{ EBV } & \multirow{5}{*}{$\mathrm{P}$ and $\mathrm{A}$} & HL vs. AML & $\mathrm{HR}=3.53(1.51-8.25) ; p=0.004$ \\
\hline & & & NHL vs. AML & $\mathrm{HR}=0.678(0.249-1.848) ; p=0.448$ \\
\hline & & & MPD vs. AML & $\mathrm{HR}=2.01(0.828-4.858) ; p=0.123$ \\
\hline & & & CLL vs. AML & $\mathrm{HR}=3.767(1.375-10.322) ; p=0.01$ \\
\hline & & & Other disease vs. AML & $\mathrm{HR}=1.449(0.486-4.319) ; p=0.506$ \\
\hline Sanz, 2014 [88] & EBV & $\mathrm{P}$ and $\mathrm{A}$ & $\begin{array}{l}\text { Hodgkin's disease vs. other } \\
\text { diagnosis }\end{array}$ & SHR = $11.6(3.4-40.0) ; p<0.0001$ \\
\hline Zhou, 2020 [101] & EBV & $\mathrm{P}$ and $\mathrm{A}$ & Underlying disease (AA vs. AL) & $\mathrm{HR}=4.369(0.484-39.451) ; p=0.189$ \\
\hline \multirow{6}{*}{ Fujimoto, 2019 [55] } & \multirow{5}{*}{ PTLD } & \multirow{5}{*}{$\mathrm{P}$ and $\mathrm{A}$} & ALL vs. AML/MDS & $\mathrm{HR}=1.08(0.75-1.57) ; p=0.68$ \\
\hline & & & CML/MPD vs. AML/MDS & $\mathrm{HR}=1.55(0.89-2.69) ; p=0.12$ \\
\hline & & & $\begin{array}{l}\text { Lymphoid malignancies vs. } \\
\text { AML/MDS }\end{array}$ & $\mathrm{HR}=1.33(0.92-1.92) ; p=0.13$ \\
\hline & & & AA vs. AML/MDS & $\mathrm{HR}=5.19(3.32-8.11) ; p<0.001$ \\
\hline & & & Others vs. AML/MDS & $\mathrm{HR}=1.94(0.97-3.89) ; p=0.06$ \\
\hline & \multicolumn{4}{|c|}{ Genotype } \\
\hline Bogunia-Kubik, 2005 [36] & EBV & $\mathrm{P}$ and $\mathrm{A}$ & $\begin{array}{l}\text { Recipient having IFNG } 3 / 3 \\
\text { genotype vs. other IFNG }\end{array}$ & $\mathrm{OR}=7.28 ; p=0.005$ \\
\hline Bogunia-Kubik, 2007 [35] & EBV & $\mathrm{P}$ and $\mathrm{A}$ & $\begin{array}{l}\text { Presence of CCR5 deletion mutation } \\
\text { (yes vs. no) }\end{array}$ & $\mathrm{OR}=0.17(0.034-0.803) ; p=0.026$ \\
\hline \multirow[t]{2}{*}{ Pagliuca, 2019 [82] } & PTLD & $\mathrm{P}$ and $\mathrm{A}$ & $\begin{array}{l}\text { Presence of HLA DRB1*11:01 (yes vs. } \\
\text { no) }\end{array}$ & SHR $=4.85(1.57-14.97) ; p=0.006$ \\
\hline & \multicolumn{4}{|c|}{$\begin{array}{l}\text { Recipient, donor EBV, CMV } \\
\text { serostatus }\end{array}$} \\
\hline Hiwarkar, 2013 [59] & EBV & $\mathrm{P}$ & $\begin{array}{l}\mathrm{D}+\text { and } \mathrm{R}+(\mathrm{CMV} \text { or EBV) or host } \\
\text { adenoviral infection }\end{array}$ & Significant, but NR \\
\hline \multirow{4}{*}{ Laberko, 2017 [69] } & \multirow{4}{*}{ EBV } & \multirow{4}{*}{$\mathrm{P}$ and $\mathrm{A}$} & $\mathrm{EBV} \mathrm{D}+/ \mathrm{R}-$ vs. $\mathrm{D}+/ \mathrm{R}+$ & $\mathrm{HR}=2.85(1.12-7.28) ; p=0.028$ \\
\hline & & & EBV D-/R+ vs. D+/R+ & $\mathrm{HR}=0.32(0.05-2.0) ; p=0.22$ \\
\hline & & & EBV D-/R- vs. D+/R+ & No events \\
\hline & & & EBV Unknown vs. D+/R+ & $\mathrm{HR}=1.23(0.53-2.9) ; p=0.63$ \\
\hline Lin, 2019 [72] & EBV & $\mathrm{P}$ and $\mathrm{A}$ & $\begin{array}{l}\mathrm{D} / \mathrm{R} \text { EBV serostatus (D-/R+ vs. } \\
\text { Other) }\end{array}$ & $\mathrm{HR}=1.58(1.01-2.46) ; p=0.046$ \\
\hline Uhlin, 2014 [94] & PTLD & $\mathrm{P}$ and $\mathrm{A}$ & EBV D+ R- vs. Other & SHR $=4.97(2.30-10.7) ; p<0.001$ \\
\hline Brunstein, 2006 [38] & EBV/PTLD & $\mathrm{P}$ and $\mathrm{A}$ & CMV (R- vs. R+) & $\mathrm{HR}=3.0(0.9-9.7) p=0.07$ \\
\hline
\end{tabular}


Table 2. Cont

\begin{tabular}{|c|c|c|c|c|}
\hline First Author, Year & Outcome & Study Population & Risk Factors & Estimate $(95 \% \mathrm{CI}) ; p$-Value * \\
\hline & \multicolumn{4}{|c|}{ Donor sex } \\
\hline Fan, 2016 [53] & EBV & $\mathrm{P}$ and $\mathrm{A}$ & Male donor & $\mathrm{OR}=13.24(2.006-87.387) ; p=0.007$ \\
\hline \multirow[t]{2}{*}{ Jaskula, 2010 [65] } & EBV & $\mathrm{P}$ and $\mathrm{A}$ & Female donor & $\mathrm{OR}=2.816 ; p=0.044$ \\
\hline & \multicolumn{4}{|c|}{ Donor type } \\
\hline Düver, 2020 [51] & EBV & $\mathrm{P}$ & Unrelated donor vs. Related donor & $\mathrm{OR}=5.05(1.24-20.63) ; p=0.024$ \\
\hline Marinho-Dias, 2019 [76] & EBV & $\mathrm{P}$ and $\mathrm{A}$ & Unrelated donor (yes vs. no) & $\mathrm{HR}=8.8, p=0.030$ at $\mathrm{D}+150$ \\
\hline Tsoumakas, 2019 [93] & EBV & $\mathrm{P}$ & Related donor vs. unrelated donor & $\mathrm{HR}=0.38(0.15-0.98) ; p=0.045$ \\
\hline Omar, 2009 [81] & EBV & $\mathrm{P}$ and $\mathrm{A}$ & $\begin{array}{l}\text { URD + MMRD vs. HLA-matched } \\
\text { donor }\end{array}$ & $p=0.04$ \\
\hline Pagliuca, 2019 [82] & PTLD & $\mathrm{P}$ and $\mathrm{A}$ & Unrelated (yes vs. no) & SHR $=2.11(1.00-4.45) ; p=0.051$ \\
\hline \multirow{4}{*}{ Fujimoto, 2019 [55] } & \multirow{4}{*}{ PTLD } & \multirow{4}{*}{$\mathrm{P}$ and $\mathrm{A}$} & MMRD vs. MRD & $\mathrm{HR}=4.39(2.39-8.07) ; p<0.001$ \\
\hline & & & MURD vs. MRD & $\mathrm{HR}=4.08(2.39-6.99) ; p<0.001$ \\
\hline & & & MMURD vs. MRD & $\mathrm{HR}=3.20(1.58-6.47) ; p=0.001$ \\
\hline & & & CB vs. MRD & $\mathrm{HR}=8.03(4.72-13.7) ; p<0.001$ \\
\hline $\begin{array}{c}\text { Sirvent-von } \\
\text { Bueltzingsloewen, } 2002 \\
\text { [89] }\end{array}$ & EBV & $\mathrm{P}$ and $\mathrm{A}$ & HLA incompatibility (yes vs. no) & $\mathrm{OR}=5(1.5-16.4)$ \\
\hline Torre-Cisneros, 2004 [91] & EBV & $\mathrm{P}$ and $\mathrm{A}$ & No HLA-matched sibling donor & $\mathrm{HR}=2.1(0.8-6.2) ; p=0.069$ \\
\hline Gao, $2019[56]$ & EBV & $\mathrm{P}$ and $\mathrm{A}$ & $\begin{array}{l}\text { Haploidentical donors vs. matched } \\
\text { sibling donors }\end{array}$ & $\mathrm{HR}=2.0(0.8-5.1) ; p=0.130$ \\
\hline $\mathrm{Ru}, 2020$ [86] & EBV & $\mathrm{P}$ and $\mathrm{A}$ & $\begin{array}{l}\text { HLA-haploidentical vs. } \\
\text { HLA-identical }\end{array}$ & $\mathrm{HR}=1.830(1.275-2.627) ; p=0.001$ \\
\hline Gao, $2019[56]$ & PTLD & $\mathrm{P}$ and $\mathrm{A}$ & $\begin{array}{l}\text { Haploidentical donors vs. matched } \\
\text { sibling donors }\end{array}$ & $\mathrm{HR}=2.0(0.5-8.3) ; p=0.350$ \\
\hline \multirow[t]{2}{*}{ Uhlin, 2014 [94] } & PTLD & $\mathrm{P}$ and $\mathrm{A}$ & HLA mismatch vs. match & SHR $=5.89(2.43-14.3) p<0.001$ \\
\hline & \multicolumn{4}{|c|}{ Graft source } \\
\hline Tsoumakas, 2019 [93] & EBV & $\mathrm{P}$ & PBSC vs. BM & $H R=2.51(1.04-6.05) ; p=0.041$ \\
\hline \multirow{3}{*}{ Wang, 2019 [97] } & \multirow{2}{*}{ EBV } & \multirow{2}{*}{$\mathrm{P}$ and $\mathrm{A}$} & $\mathrm{PB}+\mathrm{BM}$ vs. PB & $\mathrm{HR}=7.89 ; p=0.003$ \\
\hline & & & BM vs. PB & $\mathrm{HR}=18.69 ; p<0.001$ \\
\hline & & & Graft content & \\
\hline \multirow{2}{*}{ Christopeit, 2013 [45] } & \multirow{2}{*}{ EBV } & \multirow{2}{*}{ A } & $\mathrm{CD}^{+}$( $\geq$vs. $<$median $)$ & $\mathrm{OR}=0.11(0.02-0.78) ; p=0.027$ \\
\hline & & & $\mathrm{CD}^{+} \mathrm{CD}^{+}$( $\geq$vs. < median) & $\mathrm{OR}=0.05(0.006-0.431) ; p=0.007$ \\
\hline \multirow[t]{2}{*}{ Van Esser, 2001 [96] } & EBV & $\mathrm{P}$ and $\mathrm{A}$ & $\mathrm{CD} 34^{+}\left(>1.35 \times 10^{6} / \mathrm{kg}\right)$ & $\mathrm{HR}=2.6(1.5-4.6) ; p=0.001$ \\
\hline & & & $\begin{array}{c}\text { Conditioning regimens and GvHD } \\
\text { prophylaxis/treatment }\end{array}$ & \\
\hline Kullberg-Lindh, 2011 [68] & EBV & $\mathrm{P}$ & TBI (yes vs. no) & Slope $=1.60 ; p=0.001$ \\
\hline Liu, 2013 [74] & EBV & $\mathrm{P}$ and $\mathrm{A}$ & Intensified MAC vs. standard MAC & $\mathrm{HR}=1.72(1.03-2.88) ; p=0.038$ \\
\hline Lin, 2019 [72] & EBV & $\mathrm{P}$ and $\mathrm{A}$ & $\begin{array}{l}\text { Intensified conditioning vs. } \\
\text { standard MAC }\end{array}$ & HR = $1.73(1.18-2.54) ; p=0.005$ \\
\hline \multirow{2}{*}{ Sanz, 2014 [88] } & EBV & \multirow{2}{*}{$\mathrm{P}$ and $\mathrm{A}$} & RIC vs. MAC & $\mathrm{SHR}=6.0(2.0-17.6) ; p=0.001$ \\
\hline & PTLD & & RIC vs. MAC & SHR = $5.5(1.8-17.1) ; p=0.003$ \\
\hline Fujimoto, 2019 [55] & PTLD & $\mathrm{P}$ and $\mathrm{A}$ & RIC vs. MAC & $\mathrm{HR}=0.82(0.60-1.12) ; p=0.22$ \\
\hline Uhlin, 2014 [94] & PTLD & $\mathrm{P}$ and $\mathrm{A}$ & RIC vs. no RIC & SHR $=3.25(1.53-6.89) p=0.002$ \\
\hline Xuan, 2013 [17] & PTLD & $\mathrm{P}$ and $\mathrm{A}$ & Standard vs. intensified & $\mathrm{HR}=4.46(1.20-16.61) ; p=0.026$ \\
\hline Liu, 2013 [27] & PTLD & $\mathrm{P}$ and $\mathrm{A}$ & Intensified MAC vs. standard MAC & $p=0.018$ \\
\hline \multirow{2}{*}{ Brunstein, 2006 [38] } & \multirow{2}{*}{ EBV /PTLD } & \multirow{2}{*}{$\mathrm{P}$ and $\mathrm{A}$} & NMAC without ATG vs. MAC & $\mathrm{HR}=0.7(0.1-6.5) ; p=0.51$ \\
\hline & & & NMAC with ATG vs. MAC & $\mathrm{HR}=15.4(2.0-116.1) ; p<0.01$ \\
\hline
\end{tabular}


Table 2. Cont

\begin{tabular}{|c|c|c|c|c|}
\hline First Author, Year & Outcome & Study Population & Risk Factors & Estimate $(95 \% \mathrm{CI}) ; p$-Value * \\
\hline \multirow{2}{*}{ Van der Velden, 2013 [95] } & \multirow{2}{*}{ PTLD } & \multirow{2}{*}{ A } & MAC without ATG & $\mathrm{OR}=2.6(1.05-7.15) ; p=0.01$ \\
\hline & & & NMAC with ATG & $\mathrm{OR}=2.1(0.92-4.8) ; p=0.08$ \\
\hline Gao, 2019 [56] & PTLD & $\mathrm{P}$ and $\mathrm{A}$ & Use of fludarabine (yes vs. no) & $\mathrm{HR}=3.8(1.4-10.6) ; p=0.010$ \\
\hline Cohen, 2005 [46] & EBV & $\mathrm{P}$ & ATG vs. Campath & $\mathrm{OR}=2.09(0.83-5.29)$ \\
\hline Cesaro, 2004 [41] & EBV & $\mathrm{P}$ & Use of ATG (yes vs. no) & $\mathrm{HR}=13.0(2-96) ; p=0.01$ \\
\hline Düver, 2020 [51] & EBV & $\mathrm{P}$ & Use of ATG (yes vs. no) & OR $=10.68(1.15-98.86) ; p=0.037$ \\
\hline Gao, $2019[56]$ & EBV & $\mathrm{P}$ and $\mathrm{A}$ & Use of ATG (yes vs. no) & $\mathrm{HR}=6.3(1.6-24.0) ; p=0.008$ \\
\hline Kullberg-Lindh, 2011 [68] & EBV & $\mathrm{P}$ & Use of ATG (yes vs. no) & Slope $=1.34 ; p=0.004$ \\
\hline Juvonen, 2007 [66] & EBV & A & Use of ATG (yes vs. no) ${ }^{\ddagger}$ & $\mathrm{HR}=5.78(2.47-13.5) ; p<0.001$ \\
\hline Peric, 2011 [85] & EBV & A & Use of ATG (yes vs. no) & SHR $=4.9(1.1-21.0) ; p=0.03$ \\
\hline Fan, 2016 [53] & EBV & $\mathrm{P}$ and $\mathrm{A}$ & Use of ATG (yes vs. no) & OR = $7.69(1.17-50.49) ; p=0.034$ \\
\hline \multirow{2}{*}{ Laberko, 2017 [69] } & \multirow{2}{*}{ EBV } & \multirow{2}{*}{$\mathrm{P}$ and $\mathrm{A}$} & Horse ATG vs. no serotherapy & $\mathrm{HR}=2.47(0.95-6.38) ; p=0.063$ \\
\hline & & & Rabbit ATG vs. no serotherapy & $\mathrm{HR}=1.22(0.467-3.18) ; p=0.69$ \\
\hline Christopeit, 2013 [45] & EBV & A & Use of ATG (yes vs. no) & $\mathrm{OR}=0.83(0.17-4.01) ; p=0.820$ \\
\hline Liu, 2013 [74] & EBV & $\mathrm{P}$ and $\mathrm{A}$ & Use of ATG (yes vs. no) & $\mathrm{HR}=14.08(6.02-32.92) ; p<0.001$ \\
\hline $\mathrm{Ru}, 2020$ [86] & EBV & $\mathrm{P}$ and $\mathrm{A}$ & Use of ATG (yes vs. no) & $\mathrm{HR}=4.288(2.638-6.97) ; p<0.001$ \\
\hline Liu, 2013 [27] & PTLD & $\mathrm{P}$ and $\mathrm{A}$ & Use of ATG (yes vs. no) & $p=0.038$ \\
\hline Van der Velden, 2013 [95] & PTLD & A & Use of ATG (yes vs. no) & $\mathrm{OR}=2.4(1.3-4.2) p=0.001$ \\
\hline Landgren, 2009 [70] & PTLD & $\mathrm{P}$ and $\mathrm{A}$ & Use of ATG (yes vs. no) ${ }^{\ddagger}$ & $R R=3.8(2.5-5.8)$ \\
\hline Xuan, 2013 [16] & PTLD & $\mathrm{P}$ and $\mathrm{A}$ & Use of ATG (yes vs. no) & $\mathrm{HR}=13.03(1.67-101.58) p=0.014$ \\
\hline Fujimoto, 2019 [55] & PTLD & $\mathrm{P}$ and $\mathrm{A}$ & $\begin{array}{l}\text { Use of ATG in conditioning regimen } \\
\text { (yes vs. no) }\end{array}$ & $\mathrm{HR}=6.13(4.33-8.68) ; p<0.001$ \\
\hline Fujimoto, 2019 [55] & PTLD & $\mathrm{P}$ and $\mathrm{A}$ & $\begin{array}{l}\text { Use of ATG for GvHD treatment } \\
\text { (yes vs. no) } \neq\end{array}$ & $\mathrm{HR}=2.09(1.17-3.72) ; p=0.01$ \\
\hline Gao, 2019 [56] & PTLD & $\mathrm{P}$ and $\mathrm{A}$ & Use of ATG (yes vs. no) & $\mathrm{HR}=2.9(0.3-27.5) ; p=0.350$ \\
\hline Lin, 2019 [72] & EBV & $\mathrm{P}$ and $\mathrm{A}$ & $\begin{array}{c}\text { ATG dose }(10.0 \mathrm{mg} / \mathrm{kg} \text { vs. } 7.5 \\
\mathrm{mg} / \mathrm{kg})\end{array}$ & HR = $2.02(1.37-2.97) ; p<0.001$ \\
\hline Buyck, 2009 [40] & PTLD & $\mathrm{P}$ and $\mathrm{A}$ & Number of prior courses of ATG & $\mathrm{HR}=7.23(1.67-31.32) ; p=0.008$ \\
\hline Fan, 2016 [53] & EBV & $\mathrm{P}$ and $\mathrm{A}$ & 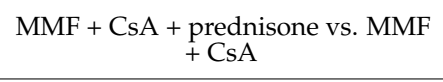 & $\mathrm{OR}=23.68(1.924-291.449) ; p=0.013$ \\
\hline \multirow[t]{2}{*}{ Christopeit, 2013 [45] } & EBV & A & $\begin{array}{c}\text { CsA AUC ( } \geq \text { vs. }<6000 \mathrm{ng} / \mathrm{mL} x \\
\text { days })\end{array}$ & $\mathrm{OR}=6.067(1.107-33.238) ; p=0.038$ \\
\hline & \multicolumn{4}{|c|}{ T-cell depletion } \\
\hline Bordon, 2012 [37] & EBV & $\mathrm{P}$ & In vivo TCD (yes vs. no) & $p=0.04$ \\
\hline Torre-Cisneros, 2004 [91] & EBV & $\mathrm{P}$ and $\mathrm{A}$ & $\begin{array}{l}\text { Use of } \mathrm{CD}^{+}{ }^{+} \text {lymphocyte-depleted } \\
\text { graft (yes vs. no) }\end{array}$ & $H R=11.5(5.8-22.8) ; p<0.0001$ \\
\hline \multirow[t]{2}{*}{ Van Esser, 2001 [96] } & \multirow[t]{2}{*}{ EBV } & \multirow[t]{2}{*}{$\mathrm{P}$ and $\mathrm{A}$} & TCD without ATG vs. non-TCD & $\mathrm{HR}=1.5(0.8-2.9) ; p=0.3$ \\
\hline & & & TCD with ATG vs. non-TCD & $\mathrm{HR}=3.4(1.6-7.1) ; p=0.001$ \\
\hline \multirow[t]{2}{*}{ Landgren, 2009 [70] } & \multirow[t]{2}{*}{ PTLD } & \multirow[t]{2}{*}{$\mathrm{P}$ and $\mathrm{A}$} & $\begin{array}{l}\text { Broad lymphocyte depletion vs. no } \\
\text { TCD }\end{array}$ & $R R=3.1(1.2-6.7)$ \\
\hline & & & Selective TCD vs. no TCD & $R R=9.4(6.0-14.7)$ \\
\hline
\end{tabular}


Table 2. Cont

\begin{tabular}{|c|c|c|c|c|}
\hline First Author, Year & Outcome & Study Population & Risk Factors & Estimate $(95 \% \mathrm{CI}) ; p$-Value * \\
\hline & & & Method of T-cell depletion & \\
\hline \multirow{6}{*}{ Landgren, 2009 [70] } & \multirow{6}{*}{ PTLD } & \multirow{6}{*}{$\mathrm{P}$ and $\mathrm{A}$} & Alemtuzumab MoAb vs. no TCD & $\mathrm{RR}=3.1(0.7-8.4)$ \\
\hline & & & $\begin{array}{l}\text { Elutriation/density gradient } \\
\text { centrifugation vs. no TCD }\end{array}$ & $\mathrm{RR}=3.2(0.8-8.8)$ \\
\hline & & & Anti-T or anti-T + NK MoAb vs. no TCD & $R R=8.4(5.1-13)$ \\
\hline & & & SRBC rosetting vs. no TCD & $R R=14.6(5.9-31)$ \\
\hline & & & $\begin{array}{l}\text { Lectins with/without SRBC or } \\
\text { anti-T MoAb vs. no TCD }\end{array}$ & $R R=15.8(7.2-32)$ \\
\hline & & & $\begin{array}{l}\text { Unclassified/unknown method vs. } \\
\text { no TCD }\end{array}$ & $\mathrm{RR}=6.0(0.96-20)$ \\
\hline & \multicolumn{4}{|c|}{ Graft-versus-host disease } \\
\hline Cohen, 2005 [46] & EBV & $\mathrm{P}$ & aGvHD (yes vs. no) & $\mathrm{OR}=2.20(2.12-15.08)$ \\
\hline Elmahdi, 2016 [52] & EBV & $\mathrm{P}$ & aGvHD (yes vs. no) & $\mathrm{HR}=3.29(1.26-8.58) ; p=0.015$ \\
\hline Hiwarkar, 2013 [59] & EBV & $\mathrm{P}$ & $\mathrm{aGvHD} \geq$ grade II & Significant, but NR \\
\hline Kullberg-Lindh, 2011 [68] & EBV & $\mathrm{P}$ & cGvHD (yes vs. no) & Slope $=-1.12 ; p=0.023$ \\
\hline Juvonen, 2007 [66] & EBV & A & $\mathrm{aGvHD} \geq$ grade $\mathrm{III}^{\ddagger}$ & $H R=1.70(1.11-2.62) ; p=0.015$ \\
\hline $\begin{array}{l}\text { Sirvent-von } \\
\text { Bueltzingsloewen, } \\
2002[89]\end{array}$ & EBV & $\mathrm{P}$ and $\mathrm{A}$ & $\mathrm{aGvHD} \geq$ grade II & OR = $3.4(1.2-9.7)$ \\
\hline Omar, 2009 [81] & EBV & $\mathrm{P}$ and $\mathrm{A}$ & aGvHD (yes vs. no) & $p=0.009$ \\
\hline Gao, $2019[56]$ & EBV & $\mathrm{P}$ and $\mathrm{A}$ & aGvHD (yes vs. no) & $\mathrm{HR}=1.0(0.7-1.6) ; p=0.960$ \\
\hline Gao, 2019 [56] & PTLD & $\mathrm{P}$ and $\mathrm{A}$ & aGvHD (yes vs. no) & $\mathrm{HR}=1.4(0.5-3.8) ; p=0.480$ \\
\hline Laberko, 2017 [69] & EBV & $\mathrm{P}$ and $\mathrm{A}$ & GvHD (yes vs. no) & $\mathrm{HR}=1.97(1.04-3.72) ; p=0.037$ \\
\hline Landgren, 2009 [70] & PTLD & $\mathrm{P}$ and $\mathrm{A}$ & $\mathrm{aGvHD} \geq$ grade $\mathrm{II}^{\ddagger}$ & $\mathrm{RR}=1.7(1.2-2.5)$ \\
\hline $\mathrm{Ru}, 2020[86]$ & EBV & $\mathrm{P}$ and $\mathrm{A}$ & $\begin{array}{l}\text { aGvHD (grade II-IV vs. none or } \\
\text { grade I) }\end{array}$ & $\mathrm{HR}=1.26(0.89-1.78) ; p=0.193$ \\
\hline Fujimoto, 2019 [55] & PTLD & $\mathrm{P}$ and $\mathrm{A}$ & aGvHD grade II-IV (yes vs. no) ${ }^{\ddagger}$ & $\mathrm{HR}=1.93(1.48-2.52) ; p<0.001$ \\
\hline Uhlin, 2014 [94] & PTLD & $\mathrm{P}$ and $\mathrm{A}$ & aGvHD $\geq$ grade II & SHR $=2.65(1.32-5.35) p=0.006$ \\
\hline Landgren, 2009 [70] & PTLD & $\mathrm{P}$ and $\mathrm{A}$ & $\begin{array}{l}\text { cGvHD moderate/severe or clinical } \\
\text { extensive }\end{array}$ & $R R=2.0(1.1-3.2)$ \\
\hline $\mathrm{Ru}, 2020[86]$ & EBV & $\mathrm{P}$ and $\mathrm{A}$ & cGvHD (yes vs. no) & $\mathrm{HR}=1.413(1.013-1.971) ; p=0.042$ \\
\hline \multirow[t]{2}{*}{ Kalra, 2018 [67] } & PTLD & $\mathrm{P}$ and $\mathrm{A}$ & $\begin{array}{l}\text { aGvHD grade II-IV or chronic NST } \\
\text { (yes vs. no) }\end{array}$ & $\mathrm{SHR}=0.47, p=0.04$ \\
\hline & \multicolumn{4}{|c|}{ Immunological reconstitution } \\
\hline Patriarca, 2013 [4] & EBV & A & $\begin{array}{c}\text { Peripheral blood CD4 } 4^{+} \\
\text {lymphocyte } / \mu \mathrm{L} \text { at }+1 \text { month after } \\
\text { HSCT }(\geq 50 \text { vs. }<50)\end{array}$ & $\mathrm{OR}=0.1(0.02-0.48) ; p=0.004$ \\
\hline Yu, 2019 [100] & EBV & $\mathrm{P}$ and $\mathrm{A}$ & $\begin{array}{l}\text { NKp30 in 1-month post-transplant } \\
(1 \mathrm{M})(\% \text { of total NK cells) }\end{array}$ & $\mathrm{HR}=0.957(0.918-0.998) ; p=0.04$ \\
\hline Liu, 2020 [73] & EBV & A & $\begin{array}{l}\mathrm{V} \delta 2^{+} \text {cell recovery at day } 30 \\
\text { post-transplantation }\end{array}$ & $\mathrm{HR}=0.347(0.161-0.747) ; p=0.007$ \\
\hline Liu, 2020 [73] & EBV & A & $\begin{array}{l}\mathrm{CD}^{+} \text {cell recovery at day } 30 \\
\text { post-transplantation }\end{array}$ & $\mathrm{HR}=0.499(0.207-1.201) ; p=0.121$ \\
\hline \multirow{2}{*}{ Xu, 2015 [98] } & PTLD & $\mathrm{P}$ and $\mathrm{A}$ & $\begin{array}{l}\mathrm{CD}^{+} \text {cell count at day } 30 \text { after } \\
\text { HSCT }(\geq \text { median vs. }<\text { median) }\end{array}$ & $\mathrm{HR}=0.34(0.13-0.92) p=0.033$ \\
\hline & PTLD & $\mathrm{P}$ and $\mathrm{A}$ & $\begin{array}{l}\text { IgM count at day } 30 \text { after HSCT } \\
(\geq \text { median vs. }<\text { median })\end{array}$ & $\mathrm{HR}=0.27(0.10-0.75) p=0.012$ \\
\hline
\end{tabular}


Table 2. Cont

\begin{tabular}{|c|c|c|c|c|c|}
\hline First Author, Year & Outcome & Study Population & \multicolumn{2}{|c|}{ Risk Factors } & Estimate $(95 \% \mathrm{CI}) ; p$-Value $*$ \\
\hline & \multicolumn{5}{|c|}{ CMV reactivation } \\
\hline Gao, 2019 [56] & EBV & $\mathrm{P}$ and $\mathrm{A}$ & \multicolumn{2}{|c|}{ CMV DNAemia (yes vs. no) } & $\mathrm{HR}=5.9(2.5-13.9) ; p<0.001$ \\
\hline Torre-Cisneros, 2004 [91] & EBV & $\mathrm{P}$ and $\mathrm{A}$ & \multicolumn{2}{|c|}{ CMV load > 2500 copies $/ \mathrm{mL}$} & $\mathrm{HR}=2.1(0.9-7) ; p=0.061$ \\
\hline Zallio, 2013 [24] & EBV & A & \multicolumn{2}{|c|}{ yes vs. no } & Significant, but NR \\
\hline Zhou, 2020 [101] & EBV & $\mathrm{P}$ and $\mathrm{A}$ & \multicolumn{2}{|c|}{ CMV DNAemia (yes vs. no) } & HR = $97.754(9.477-1008.304)$ \\
\hline Gao, $2019[56]$ & PTLD & $\mathrm{P}$ and $\mathrm{A}$ & \multicolumn{2}{|c|}{ CMV DNAemia (yes vs. no) } & $\mathrm{HR}=11.6(1.2-114.4) ; p=0.036$ \\
\hline $\mathrm{Xu}, 2015$ [98] & PTLD & $\mathrm{P}$ and $\mathrm{A}$ & \multicolumn{2}{|c|}{ CMV DNAemia (yes vs. no) } & $\mathrm{HR}=5.68(1.17-27.57) p=0.031$ \\
\hline & \multicolumn{5}{|c|}{ Transfusion } \\
\hline \multirow{8}{*}{ Trottier, 2012 [92] } & \multirow{7}{*}{ EBV } & \multirow{3}{*}{$\mathrm{P}$} & \multirow{3}{*}{$\begin{array}{c}\text { RBC } \\
\text { transfusion } \\
\text { volume }(\mathrm{mL})\end{array}$} & $<850$ vs. 0 & \multirow{3}{*}{$\begin{array}{l}p \text {-value trend }= \\
0.047\end{array}$} \\
\hline & & & & $850-1890$ vs. 0 & \\
\hline & & & & $>1890$ vs. 0 & \\
\hline & & \multirow{2}{*}{$\mathrm{P}$} & \multirow{2}{*}{$\begin{array}{c}\text { FFP } \\
\text { transfusion } \\
\text { volume }(\mathrm{mL})\end{array}$} & $\leq 200$ vs. 0 & $\begin{array}{l}\mathrm{HR}=0.70 \\
(0.22-2.25)\end{array}$ \\
\hline & & & & $>200$ vs. 0 & $\begin{array}{c}p \text {-varue trend }= \\
0.079\end{array}$ \\
\hline & & \multirow{2}{*}{$\mathrm{P}$} & \multirow{2}{*}{$\begin{array}{c}\text { PLT } \\
\text { transfusion } \\
\text { volume }(\mathrm{mL})\end{array}$} & $\begin{array}{l}1260-2530 \text { vs } \\
<1260\end{array}$ & $\begin{array}{l}\mathrm{HR}=1.65 \\
(0.86-3.18)\end{array}$ \\
\hline & & & & $>2530$ vs. $<1260$ & $\begin{array}{l}\mathrm{HR}=2.19 \\
(1.21-3.97)\end{array}$ \\
\hline & \multicolumn{5}{|c|}{ Other factors } \\
\hline \multirow{2}{*}{ Garcia-Cadenas, 2015 [57] } & EBV & A & \multicolumn{2}{|c|}{ Prior SCT (yes vs. no) } & HR: $2.6(1.1-6.4) ; p=0.04$ \\
\hline & PTLD & A & \multicolumn{2}{|c|}{ Prior SCT (yes vs. no) } & HR: $6.4(1.3-31.9) ; p=0.02$ \\
\hline Fujimoto, 2019 [55] & PTLD & $\mathrm{P}$ and $\mathrm{A}$ & \multicolumn{2}{|c|}{$\begin{array}{l}\text { Number of allogeneic HSCT (two or } \\
\text { more vs. one) }\end{array}$} & $\mathrm{HR}=1.50(1.05-2.15) ; p=0.03$ \\
\hline Landgren, 2009 [70] & PTLD & $\mathrm{P}$ and $\mathrm{A}$ & \multicolumn{2}{|c|}{ Second transplant (yes vs. no) $\neq$} & $R R=3.5(1.7-6.3)$ \\
\hline \multirow{2}{*}{ Uhlin, 2014 [94] } & PTLD & $\mathrm{P}$ and $\mathrm{A}$ & \multicolumn{2}{|c|}{ Splenectomy (yes vs. no) } & SHR $=4.81(1.51-15.4) p=0.008$ \\
\hline & PTLD & $\mathrm{P}$ and $\mathrm{A}$ & \multicolumn{2}{|c|}{ MSC treatment (yes vs. no) } & SHR $=3.05(1.25-7.48) p=0.015$ \\
\hline \multirow[b]{2}{*}{ Landgren, 2009 [70] } & \multirow[b]{2}{*}{ PTLD } & \multirow[b]{2}{*}{$P$ and $A$} & $\begin{array}{l}\text { 2+ HLA MMRD } \\
\text { selective TCD v } \\
1 \text { HLA-Ag m }\end{array}$ & $\begin{array}{l}\text { URD, no ATG, no } \\
\text { matched sibling or } \\
\text { natched relative }\end{array}$ & $\mathrm{RR}=0.9(0.3-2.2)$ \\
\hline & & & $\begin{array}{r}2+\text { HLA MN } \\
\text { and/or selecti } \\
\text { sibling } \\
\text { mismat }\end{array}$ & $\begin{array}{l}\text { or URD, ATG } \\
\text { TCD vs. matched } \\
1 \text { HLA-Ag } \\
\text { ed relative }\end{array}$ & $R R=3.8(2.4-6.1)$ \\
\hline Van Esser, 2001 [96] & PTLD & $\mathrm{P}$ and $\mathrm{A}$ & A stepwise incr & $\begin{array}{l}\text { se of EBV-DNA by } \\
\text { og }\end{array}$ & $\mathrm{HR}=2.9(1.7-4.8) ; p<0.001$ \\
\hline Pagliuca, 2019 [82] & PTLD & $\mathrm{P}$ and $\mathrm{A}$ & Fever at onset & $\begin{array}{l}\text { BV infection (yes } \\
\text { no) }\end{array}$ & $\mathrm{SHR}=6.12(1.74-21.58) ; p=0.005$ \\
\hline Fujimoto, 2019 [55] & PTLD & $\mathrm{P}$ and $\mathrm{A}$ & Year of HSC & $\begin{array}{l}(2010-2015 \text { vs. } \\
2009)\end{array}$ & $\mathrm{HR}=1.87(1.38-2.52) ; p<0.001$ \\
\hline
\end{tabular}

Abbreviations: A: adults; Ag: antigen; aGvHD: acute graft-versus-host disease; ALL: acute lymphocytic leukemia; AML: acute myeloid leukemia; ATG: anti-thymocyte globulin; AUC: area under curve; BM: bone marrow; CB: cord blood; CCR5: C-C chemokine receptor 5; cGvHD: chronic graft-versus-host disease; CI: confidence interval; CLL: chronic lymphocytic leukemia; CMV: cytomegalovirus; CsA: cyclosporine A; D+: donor positive; D-: donor negative; D/R: donor/recipient; EBV: Epstein-Barr virus; FFP: fresh-frozen plasma; GvHD: graft-versus-host disease; HL: Hodgkin's lymphoma; HLA: human leukocyte antigen; HR: hazard ratio; HSCT: hematopoietic stem cell transplantation; IFNG: interferon- $\gamma$ gene; MAC: myeloablative conditioning; MDS: myelodysplastic syndrome; MMF: mycophenolate mofetil; MMRD: mismatched related donor; MMUD: mismatched unrelated donor; MoAb: monoclonal antibody; MPD: myeloproliferative disease; MRD: matched related donor; MSC: mesenchymal stromal cells; MURD: matched unrelated donor; NHL: non-Hodgkin's lymphoproliferative disease; NK: natural killer cells; NMAC: non-myeloablative conditioning; NR: not reported; NST: needing systemic therapy; OR: odds ratio; P: pediatric; P and A: pediatric and adult; PB: peripheral blood; PBSC: peripheral blood stem cells; PTLD: posttransplant lymphoproliferative disease; PLT: platelets; R+: recipient positive; R-: recipient negative; RBC: red blood cell; RIC: reducedintensity conditioning; RR: relative risk; SCT: stem cell transplant; SHR: subhazard ratio; SRBC: sheep red blood cell; TBI: total body irradiation; TCD: T-cell depletion; URD: unrelated donor; vs.: versus. ${ }^{*}$ Time-dependent covariate. ${ }^{*}$ Statistically significant associations are shown in bold. 


\subsection{Graft-versus-Host Disease}

The association between acute (a)GvHD and post-transplant EBV infection was examined in 21 studies $[4,39,41,46,51,52,56,57,59,65,66,68,74,76,81,85,86,88,89,91,101]$. Six statistically significant associations were highlighted using different grade categorization of the outcome. In two studies, aGvHD was dichotomized in grade $\geq 3$ versus $<3$; one of them (Juvonen et al. [66]) showed that patients with aGvHD grade $\geq 3$ had a higher risk of active EBV infection ( $\mathrm{HR}=1.70(95 \% \mathrm{CI}$ : 1.11-2.62)). However, this result was not corroborated by other studies $[51,91,101]$. Among eight studies $[4,39,41,57,59,74,86,89]$ that compared grade $\geq 2$ versus $<2$, two $[59,89]$ showed that an aGvHD grade $\geq 2$ significantly increased the risk of active EBV infection, one reported a positive association without reporting the relative risk (Hiwarkar et al. [58]), and the other (Sirvent-Von Bueltzingsloewen et al. [89]) reported an OR $=3.4$ (95\% CI: 1.2-9.7). The potential effect of aGvHD, however, was not confirmed by the other studies [4,39,41,57,74]. One study (Peric et al. [85]) categorized aGvHD according to grade $0-1$, grade 2 and grades $3-4$ and did not show a statistically significant association with active EBV infection. Seven studies considered the presence versus absence of aGvHD; three highlighted a statistically significant association. Elmahdi et al. [52] showed that the presence of aGvHD, whatever the grade, increased the risk of EBV infection ( $\mathrm{HR}=3.29$ (95\% CI: 1.26-8.58)). Similar results were obtained by Cohen et al. [46] (OR = 2.2 (95\% CI: 2.12-15.08)) and by Omar et al. [81] who showed that patients with aGvHD had on average a higher EBV-VL than patients without aGvHD $(p=0.009)$. However, these results were not corroborated in four other studies $[56,65,68,76]$. Seven studies examined if chronic (c) GvHD was a risk factor of post-transplant EBV infection $[4,41,46,68,74,86,88]$, two of which showed a statistically significant relationship [68,86]. Two studies [24,69] did not differentiate aGvHD and cGvHD; one [69] showed a statistically significant association.

In regards to PTLD, its occurrence was associated with aGvHD grade $\geq 2$ in Landgren et al. $(\mathrm{RR}=1.7$ [1.2-2.5) [70], Uhlin et al. $(\mathrm{SHR}=2.65(1.32-5.35))$ [94] and Fujimoto et al. ( $\mathrm{HR}=1.93(1.48-2.52))$ [55]. No statistically significant association was identified in eight other studies $[16,27,46,56,57,88,95,98]$ that explored the association between aGvHD and PTLD. Four studies $[16,27,70,88]$ analyzed the association between cGvHD and PTLD; only Landgren et al. [70] found a statistically significant association ( $R R=2.0$ [1.1-3.2)). In contrast, the study by Kalra et al. [67]. showed a lower risk of PTLD in patients with aGvHD grade $\geq 2$ or cGvHD that required systemic therapy (SHR $=0.47 ; p=0.04$ ).

\subsection{Graft-versus-Host Disease Prophylaxis/Treatment}

ATG use appears to be an important risk factor for the development of active posttransplant EBV infection or PTLD. Among 15 multivariate studies $[4,41,45,46,51,53,56,66$, $68,69,74,79,85,86,96]$ that examined the association between ATG and active post-transplant EBV infection, 10 found a statistically significant association: Cesaro et al. [41] (HR = 13.0 (95\% CI: 2-96)), Fan et al. [53] (OR = 7.69 (95\% CI: 1.17-50.49)), Juvonen et al. [66] (HR = 5.78 (95\% CI: 2.47-13.5)), Liu et al. [74] (HR = 14.081 (95\% CI: 6.02-32.92)), Peric et al. [85] $(\mathrm{SHR}=4.9(95 \%$ CI: 1.1-21.0)), Van Esser et al. [96] (HR = 3.4 (95\% CI: 1.6-1)), Gao et al. [56] $(\mathrm{HR}=6.3(95 \%$ CI: 1.6-24.0)), Düver et al. [51] (OR = 10.68 (95\% CI: 1.15-98.86)), Ru et al. [86] $(\mathrm{HR}=4.29$ (95\% CI: 2.64-6.97)) and Kullberg-Lindh et al. [68] (slope $=1.34 ; p=0.004)$. All studies compared patients who received ATG versus those who did not, but one: Van Esser et al. [96] reported the risk of EBV infection in patients receiving T-cell depleted (TCD) grafts with ATG versus patients receiving non-TCD grafts. A statistically significant association between active post-transplant EBV infection and TCD grafts was shown by Bordon et al. [37] ( $p=0.04)$ as well as for $\mathrm{CD}^{+}$depleted grafts by Torre-Cisneros et al. [91] $(\mathrm{OR}=11.5$ (95\% CI: 5.8-22.8)). Corticosteroid use for GvHD prophylaxis (OR = 23.68 (95\% CI: 1.92-291.45)) was associated with EBV infection in the study by Fan et al. [53].

An association between ATG and PTLD was reported by Landgren et al. [70] ( $R R=3.8$ [2.5-5.8)), Van der Velden et al. [95] ( $\mathrm{OR}=2.4(1.3-4.2))$, Liu et al. [27] $(p=0.038)$, Xuan et al. [16] $(\mathrm{HR}=13.03(1.67-101.58))$ as well by Fujimoto et al. [55] (HR $=6.13$ (95\% CI: 4.33-8.68] for 
GvHD prophylaxis and HR = 2.09 (95\% CI: 1.17-3.72] for GvHD treatment). The association was not statistically significant in the study by Gao et al. [56] (HR = 2.9 (95\% CI: 0.3-27.5)). Brunstein et al. [38] found a higher risk for the composite outcome 'post-transplant EBV infection or PTLD' in patients with non-myeloablative conditioning regimen (NMAC) + ATG $($ HR $=15.4(2.0-116.1))$, but a similar risk for those receiving NMAC without ATG $(\mathrm{HR}=0.7$ (0.1-6.5) $)$ compared to those who received myeloablative conditioning (MAC). This highlights the role of ATG as a significant risk factor. Buyck et al. [40] reported a dose-response relationship: the risk of PTLD increased with the number of prior courses of ATG $(\mathrm{HR}=7.23$ (1.67-31.32)). Lin et al. [72] found a higher risk of post-transplant EBV infection in patients, who received a higher dose of ATG $(10.0 \mathrm{mg} / \mathrm{kg}$ versus $7.5 \mathrm{mg} / \mathrm{kg}$ : HR $=2.02$ (95\% CI: 1.37-2.97)). The study by Cohen et al. [46] compared patients who received Campath versus ATG; no statistically significant association was found (unadjusted $\mathrm{OR}=0.56(0.15-2.05))$.

The meta-analyses that we performed are presented in Figures 4 and 5 . The pooled HR for the association between ATG use and post-transplant EBV infection obtained using the random-effect model was 5.26 (95\% CI: 2.92-9.45) with an $\mathrm{I}^{2}=63.2 \%$ (Figure 4). We performed sensitivity analyses by recalculating the pooled estimate after excluding only one study at a time: the results vary between 4.13 and 6.49 , and the $\mathrm{I}^{2}$ heterogeneity statistic varies between $22 \%$ and $69 \%$. The studies by Laberko et al. [69] and Liu et al. [74] had the greatest influence on the pooled estimate and on the level of heterogeneity. However, regardless of the study excluded, the overall result remains statistically significant. With respect to studies that estimated an adjusted OR to report the association between ATG and post-transplant EBV infection, the pooled estimate was 2.74 [1.03-7.31] and $\mathrm{I}^{2}=40.3 \%$ (Figure 5). The sensitivity analyses highlighted a variation of the pooled estimate from 2.07 to 4.00 and of $\mathrm{I}^{2}$ from $28 \%$ to $58 \%$. The studies by Christopeit et al. [45] and Cohen et al. [46] had the greatest influence on the pooled estimate and heterogeneity. The pooled estimate was no longer significant if a single study was removed from the analysis, except for the study by Christopeit et al. [45], which was carried out with the smallest sample. The pooled RR for the association between ATG and PTLD obtained using the random-effect model was 4.17 (95\% CI: 2.61-6.68) with an $\mathrm{I}^{2}=56.7 \%$. The sensitivity analysis revealed that the pooled estimate ranged from 3.34 to 5.02 and the $\mathrm{I}^{2}$ from $9 \%$ to $67 \%$. The studies by Fujimoto et al. [55] and Van der Velden et al. [95] had the biggest influence on the pooled estimate and the $\mathrm{I}^{2}$. The sensitivity analysis did not question the statistically significant association between ATG and PTLD.

The results of these meta-analyses should be understood cautiously given the highlevel of heterogeneity observed between studies. Due to the small number of articles, we did not explore the sources of heterogeneity further by performing a subgroup analysis or a meta-regression.

\subsection{Other Risk Factors}

Other possible risk factors were analyzed in the retained studies; these factors were not associated with EBV infection or PTLD, or their relationship was more ambiguous (Table 2 and Table S4). The association between the primary diagnosis and post-transplant active EBV infection was explored in several reports $[4,23,35,39,46,56,59,69,85,86,88,101]$; three showed a strong positive and statistically significant association $[23,39,88]$. According to Carpenter et al. [23], the risk of active EBV infection was greater in patients with Hodgkin's lymphoma (HR = 3.53 (95\% CI: 1.51-8.25)) or chronic lymphocytic leukemia (HR = 3.77 (95\% CI: 1.38-10.32)) compared to patients with acute myeloid leukemia. Sanz et al. [88] reported that the risk was greater in patients with Hodgkin disease compared to other patients $(\mathrm{SHR}=11.6$ (95\% CI: 3.4-40.0)). However, Burns et al. [39] found that the risk of active post-transplant EBV infection was lower in patients with non-Hodgkin's lymphoma compared to patients with acute myeloid leukemia/myelodysplastic syndrome (AML/MDS) $(\mathrm{HR}=0.18$ (95\% CI: 0.05-0.57)). Furthermore, Fujimoto et al. [55] showed a higher risk of PTLD in patients with aplastic anemia compared to those with AML/MDS (HR = 5.19 
(95\% CI: 3.32-8.11)). No statistically significant association between the PTLD outcome and the patient's primary diagnosis was found in the other studies $[46,56,88,94,95,98]$.

\section{Meta-analysis}

Outcome: Post-transplant EBV infection/reactivation

$\begin{array}{ccccc}\begin{array}{c}\text { First } \\ \text { author }\end{array} & \text { Year } & \begin{array}{c}\text { Sample } \\ \text { size }\end{array} & \text { Population Measure } \\ & & & & \\ \text { Cesaro } & 2004 & 79 & \text { P } & \text { aHR } \\ \text { Juvonen } & 2007 & 406 & \text { A } & \text { aHR } \\ \text { Peric } & 2011 & 175 & \text { A } & \text { aSHR } \\ \text { Liu } & 2013 & 251 & \text { P \& A } & \text { aHR } \\ \text { Laberko }\left(^{*}\right) & 2017 & 182 & \text { P } & \text { aSHR } \\ \text { Gao } & 2019 & 200 & \text { P \& A } & \text { aSHR } \\ \text { Ru } & 2020 & 890 & \text { P \& A } & \text { aHR }\end{array}$

Pooled HR (Random effects model) Heterogeneity $: I^{2}=63.2 \%$

$\begin{array}{crrcc}\begin{array}{c}\text { First } \\ \text { author }\end{array} & \text { Year } & \begin{array}{c}\text { Sample } \\ \text { size }\end{array} & \text { Population Measure } \\ & & & & \\ \begin{array}{c}\text { Cohen } \\ \text { Cohen }\end{array} & 116 & \text { P } & \text { aOR } \\ \text { Christopeit } & 2013 & 28 & \text { A } & \text { aOR } \\ \text { Fan } & 2016 & 44 & \text { P \& A } & \text { aOR } \\ \text { Duver } & 2020 & 107 & \text { P } & \text { aOR }\end{array}$

Pooled OR (Random effects model) Heterogeneity $: I^{2}=40.3 \%$

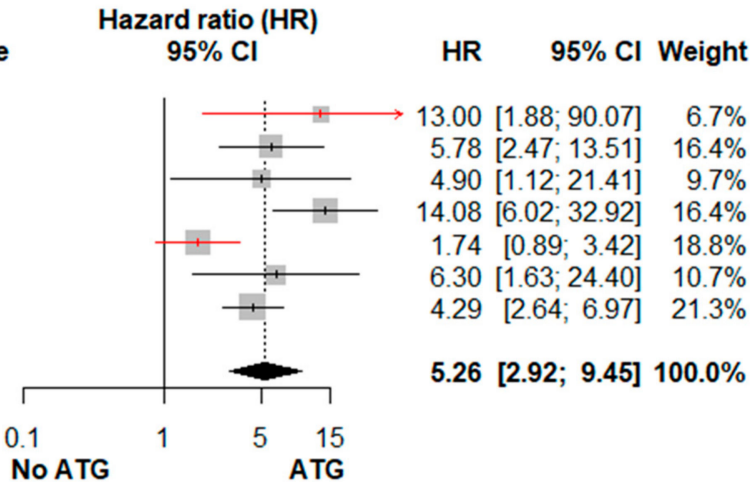

No ATG ATG $\begin{array}{rr}13.00[1.88 ; 90.07] & 6.7 \% \\ 5.78[2.47 ; 13.51] & 16.4 \% \\ 4.90[1.12 ; 21.41] & 9.7 \% \\ 14.08[6.02 ; 32.92] & 16.4 \% \\ 1.74[0.89 ; 3.42] & 18.8 \% \\ 6.30[1.63 ; 24.40] & 10.7 \% \\ 4.29[2.64 ; 6.97] & 21.3 \% \\ & \\ \mathbf{5 . 2 6}[\mathbf{2 . 9 2 ; 9 . 4 5}] & \mathbf{1 0 0 . 0 \%}\end{array}$

OR $\quad 95 \% \mathrm{Cl}$ Weight

$2.09[0.83 ; 5.28] \quad 41.4 \%$

$0.83[0.17 ; 4.01] \quad 24.5 \%$

$7.69[1.17 ; 50.50] \quad 19.2 \%$

$10.68[1.15 ; 99.02] \quad 15.0 \%$

$2.74[1.03 ; 7.31] 100.0 \%$

\section{Sensitivity analysis}

Pooled estimates obtained after one-study-removed in meta-analysis and measure of heterogeneity

\begin{tabular}{|c|c|c|c|c|c|c|c|}
\hline \multicolumn{4}{|c|}{ Pooled aHR/aSHR } & \multicolumn{4}{|c|}{ Pooled aOR } \\
\hline Study omitted & HR & $95 \% \mathrm{CI}$ & $\mathbf{I}^{2}$ & Study omitted & HR & $95 \%$ CI & $\mathbf{I}^{2}$ \\
\hline Laberko 2017 & 6.49 & $3.99-10.56$ & 0.22 & Christopeit 2013 & 4.00 & $1.31-12.19$ & 0.28 \\
\hline Liu 2013 & 4.13 & $2.46-6.93$ & 0.41 & Duver 2020 & 2.11 & $0.9-4.95$ & 0.37 \\
\hline Cesaro 2004 & 4.93 & $2.67-9.09$ & 0.67 & Fan 2016 & 2.07 & $0.85-5.07$ & 0.41 \\
\hline Juvonen 2007 & 5.24 & $2.6-10.57$ & 0.69 & Cohen 2005 & 3.61 & $0.69-18.92$ & 0.58 \\
\hline Gao 2019 & 5.19 & $2.68-10.04$ & 0.69 & & & & \\
\hline Ru 2020 & 5.64 & $2.73-11.66$ & 0.69 & & & & \\
\hline Peric 2011 & 5.35 & $2.78-10.33$ & 0.69 & & & & \\
\hline
\end{tabular}

Figure 4. Forest plots for the association between ATG use and post-transplant EBV infection according to studies estimating adjusted HR/SHR and adjusted OR. (*) In the study by Laberko et al., two estimates of the hazard ratio (HR) of the association between the use of ATG and post-transplant EBV infection were reported, corresponding to the use of horse ATG on one hand and rabbit ATG on the other. These two HRs were combined using a meta-analysis with inverse variance as a method. The results obtained were used to carry out the meta-analysis, including the other studies. Abbreviations: OR: odds ratio; HR: hazard ratio; SHR: subhazard ratio; CI: confidence intervals; ATG: anti-thymocyte globulin. 


\section{Meta-analysis}

Post-transplant lymphoproliferative disease (PTLD)

$\begin{array}{ccccc}\begin{array}{c}\text { First } \\ \text { author }\end{array} & \text { Year } & \begin{array}{c}\text { Sample } \\ \text { size }\end{array} & \text { Population Measure } \\ & & & & \\ \text { Landgren } & 2009 & 26,901 & \text { P \& A } & \text { aRR } \\ \text { Xuan } & 2013 & 263 & \text { P \& A } & \text { aHR } \\ \text { Van der Velden } & 2013 & 273 & \text { A } & \text { aOR } \\ \text { Fujimoto } & 2019 & 64,539 & \text { P \& A } & \text { aHR } \\ \text { Gao } & 2019 & 200 & \text { P \& A } & \text { aSHR }\end{array}$

Pooled HR (Random effects model) Heterogeneity $: I^{2}=56.7 \%$
Relative risk (RR) $95 \% \mathrm{Cl}$

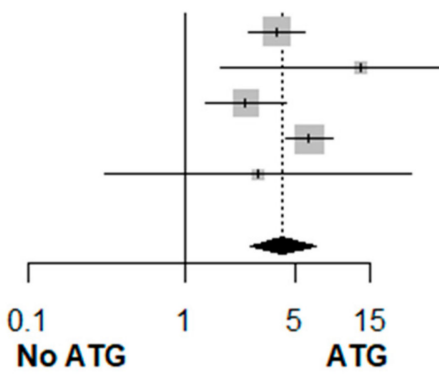

RR $\quad 95 \% \mathrm{Cl}$ Weight

$3.80 \quad[2.49 ; 5.79] \quad 31.6 \%$

$13.03[1.67 ; 101.62] \quad 4.7 \%$

$2.40[1.34 ; 4.31] \quad 25.5 \%$

$6.13 \quad[4.33 ; 8.68] \quad 34.3 \%$

$2.90[0.30 ; 27.77] \quad 3.9 \%$

$4.17[2.61 ; 6.68] 100.0 \%$

\section{Sensitivity analysis}

Pooled estimates obtained after one-study-removed in meta-analysis and mesure of heterogeneity

\begin{tabular}{lccc}
\hline Study omitted & RR & $\mathbf{9 5 \%}$ CI & $\mathbf{I}^{\mathbf{2}}$ \\
\hline Fujimoto 2019 & 3.34 & $2.25-4.97$ & 0.09 \\
\hline Van der Velden 2013 & 5.02 & $3.30-7.64$ & 0.25 \\
\hline Xuan 2013 & 3.94 & $2.41-6.44$ & 0.63 \\
\hline Landgren 2009 & 4.37 & $2.14-8.91$ & 0.64 \\
\hline Gao 2019 & 4.24 & $2.58-6.98$ & 0.67 \\
\hline
\end{tabular}

Figure 5. Forest plots for the association between ATG use and post-transplant lymphoproliferative disease (PTLD). Abbreviations: OR: odds ratio; HR: hazard ratio; SHR: subhazard ratio; CI: confidence intervals; ATG: anti-thymocyte globulin.

The use of reduced-intensity conditioning regimen was determined as a risk factor for post-transplant EBV infection by Sanz et al. [88] (SHR $=6.0(2.0-17.6))$ and as a risk factor for PTLD by Sanz et al. [88] (SHR = $5.5(1.8-17.1)$ ) and Uhlin et al. [94] (SHR = $3.25(1.53-6.89)$ ). Two studies reported that intensified myeloablative conditioning regimen (MAC) increased the risk of post-transplant EBV infection: Liu et al. [74] $(\mathrm{HR}=1.72(1.03-2.88))$ and Lin et al. [72] ( $\mathrm{HR}=1.73$ (95\% CI: 1.18-2.54)). Liu et al. [74] also found an association between intensified MAC and PTLD ( $p=0.018)$, but Xuan et al. [16] found an association in the opposite direction (standard versus intensified regimen: HR $=4.46(1.20-16.61)$ ). Gao et al. [56] found that the use of fludarabine would increase the risk of PTLD (HR $=3.8$ (1.4-10.6)). EBV viral load was higher in the study by Kullberg-Lindh et al. [68] when total body irradiation (TBI) was performed.

Recipient age did not seem to be an important risk factor for active EBV infection post-transplant. Of the 20 studies $[4,23,35,39,50-52,56,65,68,69,74,76,85,86,88,89,93,96,101]$ to consider this factor, only Bogunia-Kubik et al. [35] highlighted a statistically significant association, showing that the propensity for active post-transplant EBV infection was higher in people over 25 years compared to others ( $\mathrm{OR}=1.54$ (95\% CI: 1.14-2.70)). Concerning the association between age and PTLD, only two $[56,70]$ of the 10 studies $[16,27,40,56,67,70,88$, $94,95,98]$ that explored this factor indicated a statistically significant association. A higher risk of PTLD has been observed in patients aged 50 years or more $(\mathrm{RR}=5.1(2.8-8.7))$ [70]. Conversely, a lower risk of PTLD was observed in patients 40 years or older in another study $(\mathrm{HR}=0.4(0.2-0.9))[56]$. 
Several studies used multivariate analysis to examine the relationship between recipient sex and post-transplant active EBV infection $[4,35,39,50,52,56,65,68,69,72,74,76,85,86,88$, $89,96,101]$ or PTLD $[16,27,40,56,88,94,95,98]$; none found a significant association. Three out of six studies $[35,53,56,65,79,101]$ that analyzed the association between donor sex and postHSCT active EBV infection showed a statistically significant association but in the opposite direction. In two studies, the risk for active EBV infection post-HSCT was higher in patients receiving a male donor transplant $[53,56]$ while, in the other, patients receiving a female donor transplant appeared to be at greater risk [65]. The only study [56] that explored the association between donor sex and PTLD did not find a statistically significant association. Moreover, no statistically significant association was found between the donor/recipient sex combination and post-transplant EBV infection $[35,41,53,57,65]$. Among all studies that examined the sex of the dyad donor/recipient and PTLD [57,82,94,98], only one [82] found a statistically significant association suggesting a higher risk of PTLD in patients who received a transplant from a different sex donor.

With regard to viral infections, a study by Zallio et al. [24] suggests that the risk of active post-transplant EBV infection is higher in patients with CMV reactivation compared to those who are CMV negative $(p<0.05)$. Similar results were found by Gao et al. (HR = 5.9 (2.5-13.9)) [56] and by Zhou et al. (HR = 97.75 (9.48-1008.30)) [101]. Xu et al. [98] and Gao et al. [56] found that the risk of PTLD was higher in patients with CMV DNAemia: $\mathrm{HR}=5.68$ (1.17-7.57) and HR = 11.6 (1.2-114.4), respectively. According to Lakerko et al. [69], the risk of post-transplant EBV active infection was higher among EBV seronegative patients (compared to seropositive patients) in HSCT recipients receiving a graft from an EBV-seropositive donor ( $\mathrm{HR}=2.85$ (95\% CI: 1.12-7.28)). Lin et al. [72] found a higher risk of post-transplant EBV infection in EBV-seropositive patients who received an EBV-negative graft $(\mathrm{HR}=1.58(1.01-2.46))$. Other risk factors associated with active EBV infection posttransplant include: (1) two human genotypes, namely the interferon- $\gamma(\mathrm{IFN \gamma})$ gene $3 / 3$ $(\mathrm{OR}=7.28 ; p=0.005)[36]$ and the CC-chemokine receptor-5 (CCR5) $(\mathrm{OR}=0.17$ (95\% CI: $0.03-0.80)$ ) [35], (2) the volume of platelets transfused (>2530 vs. $<1260 \mathrm{~mL})(\mathrm{HR}=2.19(95 \%$ CI: 1.21-3.97)) [92], (3) unrelated or mismatched related donor $(p=0.04)$ [81], (4) unrelated donor $((\mathrm{HR}=8.8, p=0.030)$ [76], $(\mathrm{OR}=5.05$ (1.24-20.63)) [51], $(\mathrm{HR}=2.63(1.02-6.67))$ [93]), (5) HLA incompatibility $\left(\left(\mathrm{OR}=5\right.\right.$ [1.5-16.4)) [89], $(\mathrm{HR}=1.83(1.27-2.63))$ [86]), (6) $\mathrm{CD}^{+}$ count in the graft $\geq$ median $\left(\mathrm{OR}=0.11(0.02-0.78)\right.$ [ [4], (7) $\mathrm{CD}^{+} \mathrm{CD}^{+}$count in the graft $\geq$ median (OR $=0.05(0.01-0.43))$ [45], (8) $\mathrm{CD} 34^{+}$count in the graft $>1.35 \times 10^{6} / \mathrm{kg}(\mathrm{HR}=2.6$ (1.5-4.6)) [96], (9) CD4 $4^{+}$lymphocyte/ $\mu$ lat one month after HSCT $\geq 50(\mathrm{OR}=0.1(0.02-$ $0.481))$ [4], (10) $\mathrm{V} \delta 2^{+} \mathrm{T}$ cell count 30 days post-transplant $(\mathrm{HR}=0.347(0.161-0.747))$ [73], (11) IgM level $\geq$ median 30 days after HSCT (HR $=0.27(0.10-0.75)$ ) [98], (12) proportion (\%) of NKp30/total NK cells one month after HSCT (HR = $0.96(0.918-0.998))$ [100], and (13) prior HSCT $(\mathrm{HR}=2.6(1.1-6.4))$ [57]. Also, a higher risk of post-transplant EBV infection was observed by Tsoumakas et al. [93] in patients receiving a peripheral blood transplant compared to those receiving a bone marrow transplant $(\mathrm{HR}=2.51(1.04-6.05))$, but an opposite result was found by Wang et al. [97] $(\mathrm{HR}=18.69 ; p<0.001)$.

Other factors associated with PTLD include: $(1) \mathrm{CD}^{+}$count ( $\geq$median vs. $<$median) 30 days after HSCT $(\mathrm{HR}=0.34(0.13-0.92))$, (2) prior HSCT $((\mathrm{HR}=2.6(1.1-6.4))$ [57], $(\mathrm{RR}=3.5$ [1.7-6.3)) [70]), (3) splenectomy (SHR = 4.81 (1.51-15.4)) [94], (4) infusion of mesenchymal stromal cells (SHR = $3.05(1.25-7.48)$ ) [94], (5) a stepwise increase of EBV-DNA by $1 \log (\mathrm{HR}=2.9(1.7-4.8))$ [96], (6) HLA DRB1*11:01 (SHR = 4.85 (1.57-14.97)) [82], and (7) HLA mismatch (SHR = 5.89 (2.43-14.3)) [94]. Fujimoto et al. [55] found that, compared to matched related donor grafts, the risk of PTLD is higher when using mismatched related donor grafts $(\mathrm{HR}=4.39(2.39-8.07))$, matched unrelated donor grafts $(\mathrm{HR}=4.08(2.39-6.99))$, mismatched unrelated donor grafts $(\mathrm{HR}=3.20(1.58-6.47))$ or cord blood grafts $(\mathrm{HR}=8.03$ $(4.72-13.7))$. 


\section{Discussion}

This systematic review includes 77 papers. It aims to characterize risk factors associated with active post-transplant EBV infection and PTLD in HSCT recipients. Active EBV infection can result in rapidly increasing EBV-VL, which is a high-risk marker for PTLD development. Proper identification of the risk factors associated with active EBV infection and PTLD is needed for effective patient management.

In this systematic review, we focused on risk factors explored in published studies; very few statistically significant associations were found. The use of ATG was identified as one of the most important risk factors for the development of active post-transplant EBV infection and PTLD. The pooled relative risks estimated from the meta-analysis that was carried out confirmed a positive and statistically significant association between ATG and EBV infection ( $R R=3.98$ (95\% CI: 2.20-7.18) and PTLD ( $R R=3.69$ (95\% CI: 2.24-6.08)). ATG is a potent immunosuppressive agent that obliterates the T-cell pool [104-106], thereby enabling reactivation of latent EBV contained in mature $B$ cells along with the malignant expansion of infected cells [104]. In the HSCT setting, ATG is used for the prevention of aGvHD, given its ability to target and deplete T lymphocytes [107,108].

Some studies included in this review also found an association with the presence of GvHD, which is an immune-mediated complication of HSCT whereby donor T cells present in the graft initiate an alloreactive process that ultimately causes destruction of host tissues [109]. aGvHD usually occurs within the first three months post-transplant and is categorized into four grades ranging from 1 (light disease) to 4 (severe disease) [110]. cGvHD usually occurs beyond the initial three months post-transplant. The pathophysiology of GvHD, especially that of cGvHD, is complex [111]. T and B lymphocytes are probably involved in the pathophysiology of GvHD, although the mechanism linking these cells to GvHD is not well-known [108]. In short, the etiology of GvHD is complex, and it is difficult to conclude whether GvHD is an independent risk factor for EBV and PTLD or whether the relationship found in some studies is the result of confounding by indication related to the use of ATG. The analyses that we are currently running among pediatric HSCT recipients recruited in our TREASuRE cohort study [112] confirm that EBV is strongly associated with ATG but not with GvHD, following adequate control for confounding bias.

Many other variables were analyzed in the 77 included studies, but results were either inconsistent, failed to find an association, or limited in terms of the number of studies that investigated the risk factor. Some studies showed that primary diagnosis was associated with post-transplant active EBV infection $[23,39,88]$, more specifically in the case of Hodgkin disease [23,88]. Some forms of Hodgkin's lymphoma are etiologically linked to EBV $[113,114]$ and may occur in individuals who are not able to properly control EBV infection. These individuals may be thought to be more susceptible to other EBV diseases (such as post-transplant active EBV infection) along the continuum of care, but HSCT should have corrected any immune cell problem. Although interesting, further studies are needed to confirm the potential association between Hodgkin's disease and post-transplant active EBV infection in HSCT patients.

Discordant results were found for other variables, and, in other cases, the number of studies investigating risk factors was limited. These variables are recipient age, recipient gender, donor type, conditioning regimen, graft source, graft history, graft content $\left(\mathrm{CD} 34^{+}\right.$, $\mathrm{CD}^{+}, \mathrm{CD}^{+}, \mathrm{CD}^{+} / \mathrm{CD}^{+}$), genotype (IFNygene 3/3, CCR5), splenectomy, mesenchymal stromal cells, donor gender and transfusion (red blood cells, platelets, plasma) (Table S4). In our recent study, although no relationship was statistically found between EBV and blood product transfusion, we linked a case of EBV infection in an EBV-seronegative pediatric HSCT recipient to a blood donor through viral genotype analysis [112]. One cause of discordant results is the heterogeneity observed among the various studies, most notably with regard to the different specimen types used to perform PCR tests (Table S3). The sensitivity of PCR tests is greater when whole blood is used as opposed to plasma [115]. Other sources of discordance include variations in the statistical approach and experimental design. We also noted the absence of controls for confounding and failure to report results 
when associations lacked statistical significance. In addition, only $42.9 \%$ of studies included in the systematic review of factors associated with post-transplant EBV infection were classified as being of strong quality, and $23.8 \%$ were classified as moderate quality; with respect to PTLD as an outcome, the proportions were, respectively $57.1 \%$ and $14.3 \%$. An important risk for bias includes uncontrolled confounding bias and the lack of information on retention, a potential source of selection bias in cohort studies.

This review was not able to discern whether differences exist between children and adults. While statistical power was higher in studies combining both groups, differences in terms of risk factors may exist. Immune restoration through T-cell reconstitution after transplantation is different in children and adults [116], and risk factors may differ. It should be noted that 25 of the 77 studies selected in this systematic review have a sample size of less than 100; therefore, it is possible that type II error may explain why positive associations were not statistically significant in many studies. Moreover, the included studies were limited to the identification of factors associated with the first occurrence of active EBV infection post-transplant, although during follow-up a patient may experience several episodes of active EBV infection $[23,116]$. This latter aspect should be considered in order to better understand the dynamics of the evolution of active EBV infection posttransplant in HSCT recipients. Risk factors for the occurrence of active EBV infection may be different from those that explain the dynamics of infection. Finally, there was insufficient information on attrition, which may be the primary source of selection bias in this type of study. While we initially intended to perform a meta-analysis of all risk factors associated with active EBV infection and PTLD, this was not possible because of the diversity of outcome definitions, the variability in the definition of risk factors and the non-systematic reporting of point estimates, confidence intervals and $p$-values. However, as indicated above, a meta-analysis was carried out to measure the association between ATG use and post-transplant EBV infection and PTLD, respectively. The results, however, must be considered with caution, as the definition of outcome was quite variable from one study to another. Based on all the above arguments, further studies using large cohorts of children and adults are needed to better elucidate the determinants of active EBV infection and PTLD among HSCT recipients.

In conclusion, we found ATG as the most important risk factor for the development of active post-transplant EBV infection and PTLD in HSCT patients. ATG considerably increases the risk of EBV and PTLD. Other risk factors have been linked with EBV and PTLD in studies, such as GvHD or type of donor, but the association for these other factors is less clear due to conflicting results, the potential for bias, particularly confounding, or because of the low number of studies that considered these risk factors. Further studies using large cohorts of children and adults with appropriate control for confounding are needed to better characterize other determinants of active EBV infection and PTLD among HSCT recipients.

Supplementary Materials: The following are available online at https:/ / www.mdpi.com/2076-3 93X/9/3/288/s1, Table S1: Search equation used in Medline and EMBASE, Table S2a: Component ratings of study (a modified version of the Effective Public Health Practice Project (EPHPP) Quality Assessment Tool for Quantitative Studies, Table S2b: Results of the quality evaluation of the 77 articles included in this systematic review, Table S3: Characteristics of the 77 studies included in the systematic review and Table S4: Risk factors for post-transplant EBV infection and for PTLD explored in the 77 retained studies.

Author Contributions: P.R.E.B.: developed the study protocol, performed the research and the selection of articles, carried out the data extraction and synthesis, elaborated the draft of the evaluation grid of selected articles, evaluated the quality of the articles, wrote the first draft of the manuscript and performed updates of the manuscript. M.Z.: conducted the research and selection of articles, performed the data extraction, revised the evaluation grid of the articles, assessed the quality of the articles and revised all versions of the manuscript. C.B., M.D., J.L.: provided clinical expertise for analysis and interpretation and revised the versions of the manuscript. L.L.: checked all the data extracted and proofread all versions of the manuscript. C.A.: provided expertise on EBV, revised all 
versions of the manuscript and co-supervised all steps. H.T.: validated the results of article selection, revised and validated the evaluation grid of articles, revised all versions of the manuscript and supervised all steps. All authors have read and agreed to the published version of the manuscript.

Funding: This study was supported by a grant from the Canadian Blood Services (grant CBS \#201209293922) to HT, CB, MD, JL, CA, as well as by an operating grant from the Cancer Research Society and the C17 Council (OG \#23276) to CA for review of the pediatric studies. PREB was supported by doctoral awards from the CHU Sainte-Justine and Université de Montréal (tuition fee waiver scholarships for international students and graduate scholarship for the final year of PhD studies). HT holds a salary award (Chercheur-Boursier, Junior-2) from the Fonds de la recherche du Québec en santé (FRQ-S) and from Canadian Institutes of Health Research (CIHR) (New investigator salary award).

Institutional Review Board Statement: Not applicable.

Informed Consent Statement: Not applicable (we did a systematic review and meta-analysis of published studies).

Data Availability: We confirm that our data are available.

Acknowledgments: We thank Sylvie Fontaine, librarian at the paramedical library of the Université de Montréal, for her support in the identification of descriptors and keywords in the Medline and EMBASE databases.

Conflicts of Interest: The authors of this manuscript have no conflicts of interest to disclose.

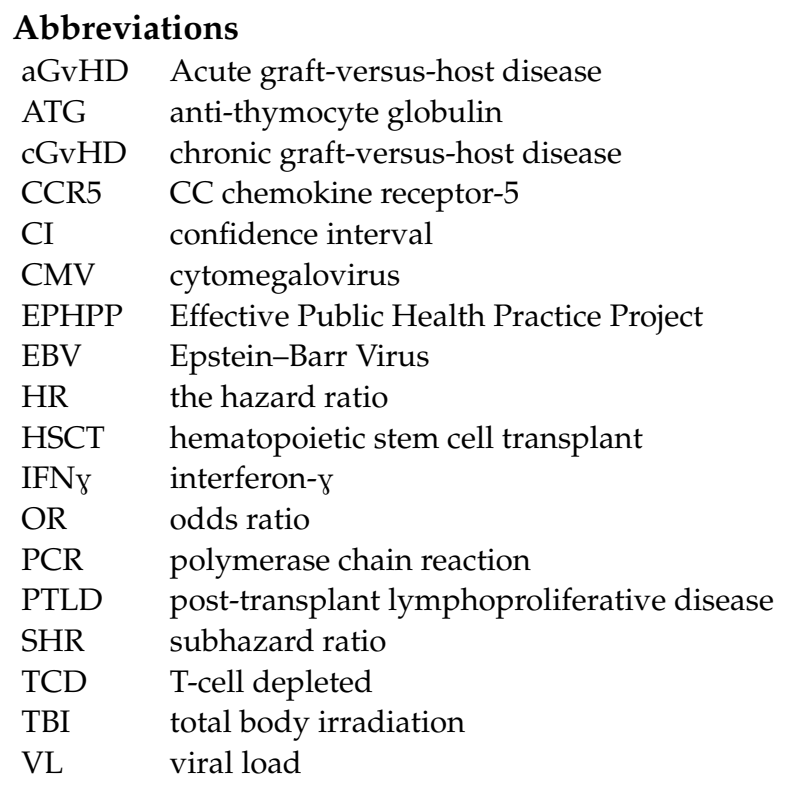

\section{References}

1. Aalto, S.M.; Juvonen, E.; Tarkkanen, J.; Volin, L.; Haario, H.; Ruutu, T.; Hedman, K. Epstein-Barr viral load and disease prediction in a large cohort of allogeneic stem cell transplant recipients. Clin. Infect. Dis. 2007, 45, 1305-1309. [CrossRef]

2. Faraci, M.; Caviglia, I.; Morreale, G.; Lanino, E.; Cuzzubbo, D.; Giardino, S.; Di Marco, E.; Cirillo, C.; Scuderi, F.; Dallorso, S.; et al. Viral-load and B-lymphocyte monitoring of EBV reactivation after allogeneic hemopoietic SCT in children. Bone Marrow Transplant. 2010, 45, 1052-1055. [CrossRef] [PubMed]

3. Herreman, A.; Dierickx, D.; Morscio, J.; Camps, J.; Bittoun, E.; Verhoef, G.; De Wolf-Peeters, C.; Sagaert, X.; Tousseyn, T. Clinicopathological characteristics of posttransplant lymphoproliferative disorders of T-cell origin: Single-center series of nine cases and meta-analysis of 147 reported cases. Leuk. Lymphoma 2013, 54, 2190-2199. [CrossRef] [PubMed]

4. Patriarca, F.; Medeot, M.; Isola, M.; Battista, M.L.; Sperotto, A.; Pipan, C.; Toffoletti, E.; Dozzo, M.; Michelutti, A.; Gregoraci, G.; et al. Prognostic factors and outcome of Epstein-Barr virus DNAemia in high-risk recipients of allogeneic stem cell transplantation treated with preemptive rituximab. Transpl. Infect. Dis. 2013, 15, 259-267. [CrossRef]

5. Rasche, L.; Kapp, M.; Einsele, H.; Mielke, S. EBV-induced post transplant lymphoproliferative disorders: A persisting challenge in allogeneic hematopoetic SCT. Bone Marrow Transplant. 2014, 49, 163-167. [CrossRef] 
6. Reddy, N.; Rezvani, K.; Barrett, A.J.; Savani, B.N. Strategies to prevent EBV reactivation and posttransplant lymphoproliferative disorders (PTLD) after allogeneic stem cell transplantation in high-risk patients. Biol. Blood Marrow Transplant. 2011, 17, 591-597. [CrossRef] [PubMed]

7. Styczynski, J.; Einsele, H.; Gil, L.; Ljungman, P. Outcome of treatment of Epstein-Barr virus-related post-transplant lymphoproliferative disorder in hematopoietic stem cell recipients: A comprehensive review of reported cases. Transpl. Infect. Dis. 2009, 11, 383-392. [CrossRef] [PubMed]

8. International Agency for Research on Cancer (IARC). Epstein-Barr Virus and Kaposi's Sarcoma Herpesvirus/Human Herpesvirus 8. In Proceedings of the IARC Working Group on the Evaluation of Carcinogenic Risks to Humans, Lyon, France, 17-24 June 1997; Volume 70, pp. 1-492.

9. Allen, U.; Alfieri, C.; Preiksaitis, J.; Humar, A.; Moore, D.; Tapiero, B.; Tellier, R.; Green, M.; Davies, D.; Hebert, D.; et al. Epstein-Barr virus infection in transplant recipients: Summary of a workshop on surveillance, prevention and treatment. Can. J. Infect. Dis. 2002, 13, 89-99. [CrossRef] [PubMed]

10. Pariente, M.; Bartolome, J.; Lorente, S.; Crespo, M.D. Age distribution of serological profiles of Epstein-Barr virus infection: Review of results from a diagnostic laboratory. Enferm. Infecc. Microbiol. Clin. 2007, 25, 108-110. [CrossRef]

11. Corssmit, E.P.; Hall, M.A.L.-V.; Portegies, P.; Bakker, P. Severe neurological complications in association with Epstein-Barr virus infection. J. Neurovirol. 1997, 3, 460-464. [CrossRef]

12. Jenson, H.B. Acute complications of Epstein-Barr virus infectious mononucleosis. Curr. Opin. Pediatr. 2000, 12, 263-268. [CrossRef] [PubMed]

13. Parkin, D.M. The global health burden of infection-associated cancers in the year 2002. Int. J. Cancer 2006, 118, 3030-3044. [CrossRef]

14. Cohen, J.I. Epstein-Barr virus lymphoproliferative disease associated with acquired immunodeficiency. Medicine 1991, 70, 137-160. [CrossRef]

15. Cohen, J.I. Epstein-Barr virus infection. N. Engl. J. Med. 2000, 343, 481-492. [CrossRef] [PubMed]

16. Xuan, L.; Jiang, X.; Sun, J.; Zhang, Y.; Huang, F.; Fan, Z.; Guo, X.; Dai, M.; Liu, C.; Yu, G.; et al. Spectrum of Epstein-Barr virus-associated diseases in recipients of allogeneic hematopoietic stem cell transplantation. Transplantation 2013, 96, 560-566. [CrossRef]

17. Tanner, J.; Alfieri, C. The Epstein-Barr virus and post-transplant lymphoproliferative disease: Interplay of immunosuppression, EBV, and the immune system in disease pathogenesis. Transpl. Infect. Dis. 2001, 3, 60-69. [CrossRef] [PubMed]

18. Curtis, R.E.; Travis, L.B.; Rowlings, P.A.; Socie, G.; Kingma, D.W.; Banks, P.M.; Jaffe, E.S.; Sale, G.E.; Horowitz, M.M.; Witherspoon, R.P.; et al. Risk of lymphoproliferative disorders after bone marrow transplantation: A multi-institutional study. Blood 1999, 94, 2208-2216. [PubMed]

19. Faye, A.; Vilmer, E. Post-Transplant Lymphoproliferative Disorder in Children. Paediatr. Drugs 2005, 7, 55-65. [CrossRef]

20. Kinch, A.; Oberg, G.; Arvidson, J.; Falk, K.I.; Linde, A.; Pauksens, K. Post-transplant lymphoproliferative disease and other Epstein-Barr virus diseases in allogeneic haematopoietic stem cell transplantation after introduction of monitoring of viral load by polymerase chain reaction. Scand. J. Infect. Dis. 2007, 39, 235-244. [CrossRef]

21. Hussein, K.; Tiede, C.; Maecker-Kolhoff, B.; Kreipe, H. Posttransplant lymphoproliferative disorder in pediatric patients. Pathobiology 2013, 80, 289-296. [CrossRef]

22. Blaes, A.H.; Cao, Q.; Wagner, J.E.; Young, J.A.; Weisdorf, D.J.; Brunstein, C.G. Monitoring and preemptive rituximab therapy for Epstein-Barr virus reactivation after antithymocyte globulin containing nonmyeloablative conditioning for umbilical cord blood transplantation. Biol. Blood Marrow Transplant. 2010, 16, 287-291. [CrossRef] [PubMed]

23. Carpenter, B.; Haque, T.; Dimopoulou, M.; Atkinson, C.; Roughton, M.; Grace, S.; Denovan, S.; Fielding, A.; Kottaridis, P.D.; Griffiths, P.; et al. Incidence and dynamics of Epstein-Barr virus reactivation after alemtuzumab-based conditioning for allogeneic hematopoietic stem-cell transplantation. Transplantation 2010, 90, 564-570. [CrossRef] [PubMed]

24. Zallio, F.; Primon, V.; Tamiazzo, S.; Pini, M.; Baraldi, A.; Corsetti, M.T.; Gotta, F.; Bertassello, C.; Salvi, F.; Rocchetti, A.; et al. Epstein-Barr virus reactivation in allogeneic stem cell transplantation is highly related to cytomegalovirus reactivation. Clin. Transplant. 2013, 27, E491-E497. [CrossRef] [PubMed]

25. Effective Public Health Practice Project. Quality Assessment Tool for Quantitative Studies. Hamilton, on: Effective Public Health Practice Project. Available online: https://merst.ca/wp-content/uploads/2018/02/quality-assessment-tool_2010.pdf (accessed on 30 September 2019).

26. Effective Public Health Practice Project. Dictionary for the Effective Public Health Practice Project Quality Assessment Tool For Quantitative Studies. Available online: https://merst.ca/wp-content/uploads/2018/02/qualilty-assessment-dictionary_2017 .pdf (accessed on 30 September 2019).

27. Liu, Q.F.; Ling, Y.W.; Fan, Z.P.; Jiang, Q.L.; Sun, J.; Wu, X.L.; Zhao, J.; Wei, Q.; Zhang, Y.; Yu, G.P.; et al. Epstein-Barr virus (EBV) load in cerebrospinal fluid and peripheral blood of patients with EBV-associated central nervous system diseases after allogeneic hematopoietic stem cell transplantation. Transpl. Infect. Dis. 2013, 15, 379-392. [CrossRef]

28. Borenstein, M. Introduction to Meta-Analysis; John Wiley \& Sons: Chichester, West Sussex, UK; Hoboken, NJ, USA, 2009; p. xxviii, $421 \mathrm{p}$.

29. Higgins, J.P.; Thompson, S.G.; Deeks, J.J.; Altman, D.G. Measuring inconsistency in meta-analyses. BMJ 2003, 327, 557-560. [CrossRef] 
30. Harrer, M.; Cuijpers, P.; Furukawa, T.; Ebert, D. Doing Meta-Analysis in R: A Hands-on Guide; PROTECT Lab Erlangen: Erlangen, Germany, 2019.

31. Ali, S.; Al Thubaiti, S.; Renzi, S.; Krueger, J.; Chiang, K.Y.; Naqvi, A.; Schechter, T.; Punnett, A.; Ali, M. Hemophagocytic lymphohistiocytosis is a sign of poor outcome in pediatric Epstein-Barr virus-associated post-transplant lymphoproliferative disease after allogeneic hematopoietic stem cell transplantation. Pediatr. Transplant. 2019, 23, e13319. [CrossRef]

32. Althubaiti, S.; Ali, S.; Renzi, S.; Krueger, J.; Chiang, K.Y.; Schechter, T.; Punnett, A.; Ali, M. Lymphocyte subset at time of EpsteinBarr viremia post-allogeneic hematopoietic stem cell transplantation in children may predict development of post-transplant lymphoproliferative disease: CD8:CD20 ratio as a sensitive predictor. Pediatr. Transplant. 2019, 23. [CrossRef]

33. Atay, D.; Akcay, A.; Erbey, F.; Ozturk, G. The impact of alternative donor types on viral infections in pediatric hematopoietic stem cell transplantation. Pediatr. Transplant. 2018, 22. [CrossRef]

34. Auger, S.; Orsini, M.; Ceballos, P.; Fegueux, N.; Kanouni, T.; Caumes, B.; Klein, B.; Villalba, M.; Rossi, J.F. Controlled Epstein-Barr virus reactivation after allogeneic transplantation is associated with improved survival. Eur. J. Haematol. 2014, 92, 421-428. [CrossRef]

35. Bogunia-Kubik, K.; Jaskula, E.; Lange, A. The presence of functional CCR5 and EBV reactivation after allogeneic haematopoietic stem cell transplantation. Bone Marrow Transplant. 2007, 40, 145-150. [CrossRef]

36. Bogunia-Kubik, K.; Mlynarczewska, A.; Jaskula, E.; Lange, A. The presence of IFNG 3/3 genotype in the recipient associates with increased risk for Epstein-Barr virus reactivation after allogeneic haematopoietic stem cell transplantation. Br. J. Haematol. 2005, 132, 326-332. [CrossRef] [PubMed]

37. Bordon, V.; Padalko, E.; Benoit, Y.; Dhooge, C.; Laureys, G. Incidence, kinetics, and risk factors of Epstein-Barr virus viremia in pediatric patients after allogeneic stem cell transplantation. Pediatr. Transplant. 2012, 16, 144-150. [CrossRef]

38. Brunstein, C.G.; Weisdorf, D.J.; DeFor, T.; Barker, J.N.; Tolar, J.; van Burik, J.A.; Wagner, J.E. Marked increased risk of Epstein-Barr virus-related complications with the addition of antithymocyte globulin to a nonmyeloablative conditioning prior to unrelated umbilical cord blood transplantation. Blood 2006, 108, 2874-2880. [CrossRef]

39. Burns, D.M.; Rana, S.; Martin, E.; Nagra, S.; Ward, J.; Osman, H.; Bell, A.I.; Moss, P.; Russell, N.H.; Craddock, C.F.; et al. Greatly reduced risk of EBV reactivation in rituximab-experienced recipients of alemtuzumab-conditioned allogeneic HSCT. Bone Marrow Transplant. 2016, 51, 825-832. [CrossRef] [PubMed]

40. Buyck, H.C.E.; Ball, S.; Junagade, P.; Marsh, J.; Chakrabarti, S. Prior immunosuppressive therapy with antithymocyte globulin increases the risk of EBV-related lymphoproliferative disorder following allo-SCT for acquired aplastic anaemia. Bone Marrow Transplant. 2009, 43, 813-816. [CrossRef]

41. Cesaro, S.; Murrone, A.; Mengoli, C.; Pillon, M.; Biasolo, M.A.; Calore, E.; Tridello, G.; Varotto, S.; Alaggio, R.; Zanesco, L.; et al. The real-time polymerase chain reaction-guided modulation of immunosuppression enables the pre-emptive management of Epstein-Barr virus reactivation after allogeneic haematopoietic stem cell transplantation. Br. J. Haematol. 2004, 128, $224-233$. [CrossRef]

42. Cesaro, S.; Pegoraro, A.; Tridello, G.; Calore, E.; Pillon, M.; Varotto, S.; Abate, D.; Barzon, L.; Mengoli, C.; Carli, M.; et al. A prospective study on modulation of immunosuppression for Epstein-Barr virus reactivation in pediatric patients who underwent unrelated hematopoietic stem-cell transplantation. Transplantation 2010, 89, 1533-1540. [CrossRef] [PubMed]

43. Chiereghin, A.; Prete, A.; Belotti, T.; Gibertoni, D.; Piccirilli, G.; Gabrielli, L.; Pession, A.; Lazzarotto, T. Prospective Epstein-Barr virus-related post-transplant lymphoproliferative disorder prevention program in pediatric allogeneic hematopoietic stem cell transplant: Virological monitoring and first-line treatment. Transpl. Infect. Dis. 2016, 18, 44-54. [CrossRef]

44. Chiereghin, A.; Piccirilli, G.; Belotti, T.; Prete, A.; Bertuzzi, C.; Gibertoni, D.; Gabrielli, L.; Turello, G.; Borgatti, E.C.; Barbato, F.; et al. Clinical utility of measuring Epstein-Barr virus-specific cell-mediated immunity after HSCT in addition to virological monitoring: Results from a prospective study. Med. Microbiol. Immunol. 2019, 208, 825-834. [CrossRef] [PubMed]

45. Christopeit, M.; Janssen, N.; Weber, T.; Bacher, U.; Lautenschlager, C.; Oehme, A.; Kekule, A.S.; Schmoll, H.J. Cyclosporine area under the curve after allogeneic hematopoietic stem cell transplantation is an indicator of Epstein-Barr virus DNAemia. Leuk. Lymphoma 2013, 54, 133-137. [CrossRef]

46. Cohen, J.; Gandhi, M.; Naik, P.; Cubitt, D.; Rao, K.; Thaker, U.; Davies, E.G.; Gaspar, H.B.; Amrolia, P.J.; Veys, P. Increased incidence of EBV-related disease following paediatric stem cell transplantation with reduced-intensity conditioning. Br. J. Haematol. 2005, 129, 229-239. [CrossRef]

47. Comoli, P.; Basso, S.; Zecca, M.; Pagliara, D.; Baldanti, F.; Bernardo, M.E.; Barberi, W.; Moretta, A.; Labirio, M.; Paulli, M.; et al. Preemptive therapy of EBV-related lymphoproliferative disease after pediatric haploidentical stem cell transplantation. Am. J. Transplant. 2007, 7, 1648-1655. [CrossRef] [PubMed]

48. Czyzewski, K.; Styczynski, J.; Giebel, S.; Fraczkiewicz, J.; Salamonowicz, M.; Zajac-Spychala, O.; Zaucha-Prazmo, A.; DrozdSokolowska, J.; Waszczuk-Gajda, A.; Dybko, J.; et al. Age-dependent determinants of infectious complications profile in children and adults after hematopoietic cell transplantation: Lesson from the nationwide study. Ann. Hematol. 2019, 98, $2197-2211$. [CrossRef] [PubMed]

49. D'Aveni, M.; Aissi-Rothe, L.; Venard, V.; Salmon, A.; Falenga, A.; Decot, V.; Virion, J.M.; Wang, Y.; Clement, L.; Latger-Cannard, V.; et al. The clinical value of concomitant Epstein Barr virus (EBV)-DNA load and specific immune reconstitution monitoring after allogeneic hematopoietic stem cell transplantation. Transpl. Immunol. 2011, 24, 224-232. [CrossRef] 
50. Dumas, P.Y.; Ruggeri, A.; Robin, M.; Crotta, A.; Abraham, J.; Forcade, E.; Bay, J.O.; Michallet, M.; Bertrand, Y.; Socie, G.; et al. Incidence and risk factors of EBV reactivation after unrelated cord blood transplantation: A Eurocord and Societe Francaise de Greffe de Moelle-Therapie Cellulaire collaborative study. Bone Marrow Transplant. 2013, 48, 253-256. [CrossRef] [PubMed]

51. Duver, F.; Weisbrich, B.; Eyrich, M.; Wolfl, M.; Schlegel, P.G.; Wiegering, V. Viral reactivations following hematopoietic stem cell transplantation in pediatric patients-A single center 11-year analysis. PLoS ONE 2020, 15, e0228451. [CrossRef] [PubMed]

52. Elmahdi, S.; Muramatsu, H.; Narita, A.; Torii, Y.; Ismael, O.; Kawashima, N.; Okuno, Y.; Sekiya, Y.; Xu, Y.; Wang, X.; et al. Correlation of rabbit antithymocyte globulin serum levels and clinical outcomes in children who received hematopoietic stem cell transplantation from an alternative donor. Pediatr. Transplant. 2016, 20, 105-113. [CrossRef] [PubMed]

53. Fan, J.; Jing, M.; Yang, M.; Xu, L.; Liang, H.; Huang, Y.; Yang, R.; Gui, G.; Wang, H.; Gong, S.; et al. Herpesvirus infections in hematopoietic stem cell transplant recipients seropositive for human cytomegalovirus before transplantation. Int. J. Infect. Dis. 2016, 46, 89-93. [CrossRef] [PubMed]

54. Figgins, B.; Hammerstrom, A.; Ariza-Heredia, E.; Oran, B.; Milton, D.R.; Yeh, J. Characterization of Viral Infections after Antithymocyte Globulin-Based Conditioning in Adults Undergoing Allogeneic Hematopoietic Stem Cell Transplantation. Biol. Blood Marrow Transplant. 2019, 25, 1837-1843. [CrossRef]

55. Fujimoto, A.; Hiramoto, N.; Yamasaki, S.; Inamoto, Y.; Uchida, N.; Maeda, T.; Mori, T.; Kanda, Y.; Kondo, T.; Shiratori, S.; et al. Risk Factors and Predictive Scoring System For Post-Transplant Lymphoproliferative Disorder after Hematopoietic Stem Cell Transplantation. Biol. Blood Marrow Transplant. 2019, 25, 1441-1449. [CrossRef]

56. Gao, X.N.; Lin, J.; Wang, L.J.; Li, F.; Li, H.H.; Wang, S.H.; Huang, W.R.; Gao, C.J.; Yu, L.; Liu, D.H. Risk factors and clinical outcomes of Epstein-Barr virus DNAemia and post-transplant lymphoproliferative disorders after haploidentical and matched-sibling PBSCT in patients with hematologic malignancies. Ann. Hematol. 2019, 98, 2163-2177. [CrossRef]

57. Garcia-Cadenas, I.; Castillo, N.; Martino, R.; Barba, P.; Esquirol, A.; Novelli, S.; Orti, G.; Garrido, A.; Saavedra, S.; Moreno, C.; et al . Impact of Epstein Barr virus-related complications after high-risk allo-SCT in the era of pre-emptive rituximab. Bone Marrow Transplant. 2015, 50, 579-584. [CrossRef] [PubMed]

58. Han, S.B.; Bae, E.Y.; Lee, J.W.; Jang, P.S.; Lee, D.G.; Chung, N.G.; Jeong, D.C.; Cho, B.; Lee, S.J.; Kang, J.H.; et al. Features of Epstein-Barr virus reactivation after allogeneic hematopoietic cell transplantation in Korean children living in an area of high seroprevalence against Epstein-Barr virus. Int. J. Hematol. 2014, 100, 188-199. [CrossRef] [PubMed]

59. Hiwarkar, P.; Gaspar, H.B.; Gilmour, K.; Jagani, M.; Chiesa, R.; Bennett-Rees, N.; Breuer, J.; Rao, K.; Cale, C.; Goulden, N.; et al. Impact of viral reactivations in the era of pre-emptive antiviral drug therapy following allogeneic haematopoietic SCT in paediatric recipients. Bone Marrow Transplant. 2013, 48, 803-808. [CrossRef]

60. Hoegh-Petersen, M.; Goodyear, D.; Geddes, M.N.; Liu, S.; Ugarte-Torres, A.; Liu, Y.; Walker, J.T.; Fonseca, K.; Daly, A.; Duggan, P.; et al. High incidence of post transplant lymphoproliferative disorder after antithymocyte globulin-based conditioning and ineffective prediction by day 28 EBV-specific T lymphocyte counts. Bone Marrow Transplant. 2011, 46, 1104-1112. [CrossRef]

61. Hoshino, Y.; Kimura, H.; Tanaka, N.; Tsuge, I.; Kudo, K.; Horibe, K.; Kato, K.; Matsuyama, T.; Kikuta, A.; Kojima, S.; et al. Prospective monitoring of the Epstein-Barr virus DNA by a real-time quantitative polymerase chain reaction after allogenic stem cell transplantation. Br. J. Haematol. 2001, 115, 105-111. [CrossRef]

62. Islam, M.S.; Anoop, P.; Gordon-Smith, E.C.; Rice, P.; Datta-Nemdharry, P.; Marsh, J.C. Epstein-Barr virus infections after allogeneic stem cell transplantation: A comparison between non-malignant and malignant hematological disorders. Hematology 2010, 15, 344-350. [CrossRef] [PubMed]

63. Issa, H.; Sharma, N.; Zhao, Q.; Ruppert, A.S.; Elder, P.; Benson, D.M.; Penza, S.; Vasu, S.; William, B.; Jaglowski, S.; et al. Comparison of Two Doses of Antithymocyte Globulin in Reduced-Intensity Conditioning Allogeneic Hematopoietic Stem Cell Transplantation. Biol. Blood Marrow Transplant. 2019, 25, 1993-2001. [CrossRef]

64. Kutnik, P.; Kwiatkowska, A.; Krawczyk, D.; Polak, O.; Jawoszek, P.; Puchala, D.; Zaucha-Prazmo, A.; Kowalczyk, J. The impact of donor-recipient sex matching on transplantrelated complications in children after allogeneic haematopoietic stem cell transplantation-A single-centre, retrospective study. Pediatr. Pol. 2019, 94, 158-161. [CrossRef]

65. Jaskula, E.; Dlubek, D.; Sedzimirska, M.; Duda, D.; Tarnowska, A.; Lange, A. Reactivations of cytomegalovirus, human herpes virus 6, and Epstein-Barr virus differ with respect to risk factors and clinical outcome after hematopoietic stem cell transplantation. Transplant. Proc. 2010, 42, 3273-3276. [CrossRef]

66. Juvonen, E.; Aalto, S.; Tarkkanen, J.; Volin, L.; Hedman, K.; Ruutu, T. Retrospective evaluation of serum Epstein Barr virus DNA levels in 406 allogeneic stem cell transplant patients. Haematologica 2007, 92, 819-825. [CrossRef]

67. Kalra, A.; Roessner, C.; Jupp, J.; Williamson, T.; Tellier, R.; Chaudhry, A.; Khan, F.; Taparia, M.; Jimenez-Zepeda, V.H.; Stewart, D.A.; et al. Risk factors for post-transplant lymphoproliferative disorder after Thymoglobulin-conditioned hematopoietic cell transplantation. Clin. Transplant. 2018, 32, e13150. [CrossRef]

68. Kullberg-Lindh, C.; Mellgren, K.; Friman, V.; Fasth, A.; Ascher, H.; Nilsson, S.; Lindh, M. Opportunistic virus DNA levels after pediatric stem cell transplantation: Serostatus matching, anti-thymocyte globulin, and total body irradiation are additive risk factors. Transpl. Infect. Dis. 2011, 13, 122-130. [CrossRef] [PubMed]

69. Laberko, A.; Bogoyavlenskaya, A.; Shelikhova, L.; Shekhovtsova, Z.; Balashov, D.; Voronin, K.; Kurnikova, E.; Boyakova, E.; Raykina, E.; Brilliantova, V.; et al. Risk Factors for and the Clinical Impact of Cytomegalovirus and Epstein-Barr Virus Infections in Pediatric Recipients of TCR-alpha/beta- and CD19-Depleted Grafts. Biol. Blood Marrow Transplant. 2017, 23, 483-490. [CrossRef] 
70. Landgren, O.; Gilbert, E.S.; Rizzo, J.D.; Socie, G.; Banks, P.M.; Sobocinski, K.A.; Horowitz, M.M.; Jaffe, E.S.; Kingma, D.W.; Travis, L.B.; et al. Risk factors for lymphoproliferative disorders after allogeneic hematopoietic cell transplantation. Blood 2009, 113, 4992-5001. [CrossRef] [PubMed]

71. Li, S.; Wang, B.; Fu, L.; Pang, Y.; Zhu, G.; Zhou, X.; Ma, J.; Su, Y.; Qin, M.; Wu, R. Hematopoietic stem cell transplantation without in vivo T-cell depletion for pediatric aplastic anemia: A single-center experience. Pediatr. Transplant. 2018, 22, e13204. [CrossRef] [PubMed]

72. Lin, R.; Wang, Y.; Huang, F.; Fan, Z.; Zhang, S.; Yang, T.; Xu, Y.; Xu, N.; Xuan, L.; Ye, J.; et al. Two dose levels of rabbit antithymocyte globulin as graft-versus-host disease prophylaxis in haploidentical stem cell transplantation: A multicenter randomized study. BMC Med. 2019, 17, 156. [CrossRef] [PubMed]

73. Liu, J.; Gao, H.; Xu, L.P.; Mo, X.D.; Liu, R.; Liang, S.; Wu, N.; Wang, M.; Wang, Z.; Chang, Y.J.; et al. Immunosuppressant indulges EBV reactivation and related lymphoproliferative disease by inhibiting Vdelta2+ T cells activities after hematopoietic transplantation for blood malignancies. J. Immunother. Cancer 2020, 8. [CrossRef] [PubMed]

74. Liu, Q.; Xuan, L.; Liu, H.; Huang, F.; Zhou, H.; Fan, Z.; Zhao, K.; Wu, M.; Xu, L.; Zhai, X.; et al. Molecular monitoring and stepwise preemptive therapy for Epstein-Barr virus viremia after allogeneic stem cell transplantation. Am. J. Hematol. 2013, 88, 550-555. [CrossRef]

75. Liu, J.; Bian, Z.; Wang, X.; Xu, L.P.; Fu, Q.; Wang, C.; Chang, Y.J.; Wang, Y.; Zhang, X.H.; Jiang, Z.; et al. Inverse correlation of Vdelta2(+) T-cell recovery with EBV reactivation after haematopoietic stem cell transplantation. Br. J. Haematol. 2018, 180, 276-285. [CrossRef] [PubMed]

76. Marinho-Dias, J.; Baldaque, I.; Pinho-Vaz, C.; Leite, L.; Branca, R.; Campilho, F.; Campos, A.; Medeiros, R.; Sousa, H. Association of Epstein-Barr virus infection with allogeneic hematopoietic stem cell transplantation in patients in Portugal. Mol. Med. Rep. 2019, 19, 1435-1442. [CrossRef]

77. Meijer, E.; Dekker, A.W.; Lokhorst, H.M.; Petersen, E.J.; Nieuwenhuis, H.K.; Verdonck, L.F. Low incidence of infectious complications after nonmyeloablative compared with myeloablative allogeneic stem cell transplantation. Transpl. Infect. Dis. 2004, 6, 171-178. [CrossRef] [PubMed]

78. Mountjoy, L.; Jain, T.; Kunze, K.L.; Khera, N.; Sproat, L.Z.; Jennifer, W.; McCallen, M.; Leis, J.F.; Noel, P.; Slack, J.L.; et al. Clinical outcomes with low dose anti-thymocyte globulin in patients undergoing matched unrelated donor allogeneic hematopoietic cell transplantation. Leuk. Lymphoma 2020, 61, 1996-2002. [CrossRef] [PubMed]

79. Neumann, T.; Schneidewind, L.; Thiele, T.; Pink, D.; Schulze, M.; Schmidt, C.; Krüger, W. No indication of increased infection rates using low-dose alemtuzumab instead of anti-thymocyte globulin as graft-versus-host disease prophylaxis before allogeneic stem cell transplantation. Transpl. Infect. Dis. 2018, 20, e12822. [CrossRef] [PubMed]

80. Nowak, J.; Gwozdowicz, S.; Graczyk-Pol, E.; Mika-Witkowska, R.; Rogatko-Koros, M.; Nestorowicz, K.; Szlendak, U.; Malinowska, A.; Kaczmarek, B.; Nasilowska-Adamska, B.; et al. Epstein-Barr virus infections are strongly dependent on activating and inhibitory KIR-HLA pairs after T-cell replate unrelated hematopoietic stem cell transplantation, the principles, and method of pairing analysis. HLA 2019, 94, 40-48. [CrossRef] [PubMed]

81. Omar, H.; Hagglund, H.; Gustafsson-Jernberg, A.; LeBlanc, K.; Mattsson, J.; Remberger, M.; Ringden, O.; Sparrelid, E.; Sundin, M.; Winiarski, J.; et al. Targeted monitoring of patients at high risk of post-transplant lymphoproliferative disease by quantitative Epstein-Barr virus polymerase chain reaction. Transpl. Infect. Dis. 2009, 11, 393-399. [CrossRef]

82. Pagliuca, S.; Bommier, C.; Michonneau, D.; Meignin, V.; Salmona, M.; Robin, M.; Prata, P.H.; Xhaard, A.; de Fontbrune, F.S.; Feghoul, L.; et al. Epstein-Barr Virus-Associated Post-Transplantation Lymphoproliferative Disease in Patients Who Received Anti-CD20 after Hematopoietic Stem Cell Transplantation. Biol. Blood Marrow Transplant. 2019, 25, 2490-2500. [CrossRef]

83. Park, J.; Lim, S.H.; Kim, S.H.; Yun, J.; Kim, C.K.; Lee, S.C.; Won, J.H.; Hong, D.S.; Park, S.K. Is immunological recovery clinically relevant at 100 days after allogeneic transplantation? Korean J. Intern. Med. 2020, 21. [CrossRef]

84. Peric, Z.; Cahu, X.; Chevallier, P.; Brissot, E.; Malard, F.; Guillaume, T.; Delaunay, J.; Ayari, S.; Dubruille, V.; Le Gouill, S.; et al. Features of EBV reactivation after reduced intensity conditioning unrelated umbilical cord blood transplantation. Bone Marrow Transplant. 2012, 47, 251-257. [CrossRef] [PubMed]

85. Peric, Z.; Cahu, X.; Chevallier, P.; Brissot, E.; Malard, F.; Guillaume, T.; Delaunay, J.; Ayari, S.; Dubruille, V.; Le Gouill, S.; et al. Features of Epstein-Barr Virus (EBV) reactivation after reduced intensity conditioning allogeneic hematopoietic stem cell transplantation. Leukemia 2011, 25, 932-938. [CrossRef]

86. Ru, Y.; Zhang, X.; Song, T.; Ding, Y.; Zhu, Z.; Fan, Y.; Xu, Y.; Sun, A.; Qiu, H.; Jin, Z.; et al. Epstein-Barr virus reactivation after allogeneic hematopoietic stem cell transplantation: Multifactorial impact on transplant outcomes. Bone Marrow Transplant. 2020, 55, 1754-1762. [CrossRef]

87. Rustia, E.; Violago, L.; Jin, Z.; Foca, M.D.; Kahn, J.M.; Arnold, S.; Sosna, J.; Bhatia, M.; Kung, A.L.; George, D.; et al. Risk Factors and Utility of a Risk-Based Algorithm for Monitoring Cytomegalovirus, Epstein-Barr Virus, and Adenovirus Infections in Pediatric Recipients after Allogeneic Hematopoietic Cell Transplantation. Biol. Blood Marrow Transplant. 2016, 22, 1646-1653. [CrossRef]

88. Sanz, J.; Arango, M.; Senent, L.; Jarque, I.; Montesinos, P.; Sempere, A.; Lorenzo, I.; Martin, G.; Moscardo, F.; Mayordomo, E.; et al. EBV-associated post-transplant lymphoproliferative disorder after umbilical cord blood transplantation in adults with hematological diseases. Bone Marrow Transplant. 2014, 49, 397-402. [CrossRef] 
89. Bueltzingsloewen, A.S.-V.; Morand, P.; Buisson, M.; Souillet, G.; Chambost, H.; Bosson, J.L.; Bordigoni, P. A prospective study of Epstein-Barr virus load in 85 hematopoietic stem cell transplants. Bone Marrow Transplant. 2002, 29, 21-28. [CrossRef]

90. Styczynski, J.; Gil, L.; Tridello, G.; Ljungman, P.; Donnelly, J.P.; Van Der Velden, W.; Omar, H.; Martino, R.; Halkes, C.; Faraci, M.; et al. Response to rituximab-based therapy and risk factor analysis in epstein barr virus-related lymphoproliferative disorder after hematopoietic stem cell transplant in children and adults: A study from the infectious diseases working party of the european group for blood and marrow transplantation. Clin. Infect. Dis. 2013, 57, 794-802. [PubMed]

91. Torre-Cisneros, J.; Roman, J.; Torres, A.; Herrera, C.; Caston, J.J.; Rivero, A.; Mingot, E.; Rojas, R.; Martin, C.; Martinez, F.; et al. Control of Epstein-Barr virus load and lymphoproliferative disease by maintenance of CD8+ T lymphocytes in the T lymphocyte-depleted graft after bone marrow transplantation. J. Infect. Dis. 2004, 190, 1596-1599. [CrossRef]

92. Trottier, H.; Buteau, C.; Robitaille, N.; Duval, M.; Tucci, M.; Lacroix, J.; Alfieri, C. Transfusion-related Epstein-Barr virus infection among stem cell transplant recipients: A retrospective cohort study in children. Transfusion 2012, 52, 2653-2663. [CrossRef]

93. Tsoumakas, K.; Giamaiou, K.; Goussetis, E.; Graphakos, S.; Kossyvakis, A.; Horefti, E.; Mentis, A.; Elefsiniotis, I.; Pavlopoulou, I.D. Epidemiology of viral infections among children undergoing hematopoietic stem cell transplant: Alpha prospective single-center study. Transpl. Infect. Dis. 2019, 21, e13095. [CrossRef]

94. Uhlin, M.; Wikell, H.; Sundin, M.; Blennow, O.; Maeurer, M.; Ringden, O.; Winiarski, J.; Ljungman, P.; Remberger, M.; Mattsson, J. Risk factors for Epstein-Barr virus-related post-transplant lymphoproliferative disease after allogeneic hematopoietic stem cell transplantation. Haematologica 2014, 99, 346-352. [CrossRef] [PubMed]

95. Van Der Velden, W.J.F.M.; Mori, T.; Stevens, W.B.C.; De Haan, A.F.J.; Stelma, F.F.; Blijlevens, N.M.A.; Donnelly, J.P. Reduced PTLDrelated mortality in patients experiencing EBV infection following allo-SCT after the introduction of a protocol incorporating pre-emptive rituximab. Bone Marrow Transplant. 2013, 48, 1465-1471. [CrossRef] [PubMed]

96. Van Esser, J.W.J.; Van Der Holt, B.; Meijer, E.; Niesters, H.G.M.; Trenschel, R.; Thijsen, S.F.T.; Van Loon, A.M.; Frassoni, F.; Bacigalupo, A.; Schaefer, U.W.; et al. Epstein-Barr virus (EBV) reactivation is a frequent event after allogeneic stem cell transplantation (SCT) and quantitatively predicts EBV-lymphoproliferative disease following T-cell-depleted SCT. Blood 2001, 98, 972-978. [CrossRef] [PubMed]

97. Wang, H.; Zhang, T.T.; Qi, J.Q.; Chu, T.T.; Miao, M.; Qiu, H.Y.; Fu, C.C.; Tang, X.W.; Ruan, C.G.; Wu, D.P.; et al. Incidence, risk factors, and clinical significance of Epstein-Barr virus reactivation in myelodysplastic syndrome after allogeneic haematopoietic stem cell transplantation. Ann. Hematol. 2019, 98, 987-996. [CrossRef] [PubMed]

98. Xu, L.P.; Zhang, C.L.; Mo, X.D.; Zhang, X.H.; Chen, H.; Han, W.; Chen, Y.H.; Wang, Y.; Yan, C.H.; Wang, J.Z.; et al. Epstein-Barr Virus-Related Post-Transplantation Lymphoproliferative Disorder after Unmanipulated Human Leukocyte Antigen Haploidentical Hematopoietic Stem Cell Transplantation: Incidence, Risk Factors, Treatment, and Clinical Outcomes. Biol. Blood Marrow Transplant. 2015, 21, 2185-2191. [CrossRef] [PubMed]

99. Xuan, L.; Huang, F.; Fan, Z.; Zhou, H.; Zhang, X.; Yu, G.; Zhang, Y.; Liu, C.; Sun, J.; Liu, Q. Effects of intensified conditioning on Epstein-Barr virus and cytomegalovirus infections in allogeneic hematopoietic stem cell transplantation for hematological malignancies. J. Hematol. Oncol. 2012, 5, 46. [CrossRef] [PubMed]

100. Yu, X.X.; Cao, X.H.; Yan, H.; Luo, X.Y.; Zhao, X.S.; Sun, Y.Q.; Wang, Y.; Xu, L.P.; Zhang, X.H.; Chang, Y.J.; et al. Delay expression of NKp30 on NK cells correlates with long-term mycophenolate mofetil treatment and higher EBV viremia post allogenic hematological stem cells transplantation. Clin. Immunol. 2019, 205, 49-56. [CrossRef] [PubMed]

101. Zhou, L.; Gao, Z.Y.; Lu, D.P. Incidence, risk factors, and clinical outcomes associated with Epstein-Barr virus-DNAemia and Epstein-Barr virus-associated disease in patients after haploidentical allogeneic stem cell transplantation: A single-center study. Clin. Transplant. 2020, 34. [CrossRef]

102. Zhou, L.; Gao, Z.Y.; Lu, D.P. Comparison of ATG-thymoglobulin with ATG-Fresenius for Epstein-Barr virus infections and graft-versus-host-disease in patients with hematological malignances after haploidentical hematopoietic stem cell transplantation: A single-center experience. Ann. Hematol. 2020, 99, 1389-1400. [CrossRef]

103. Sundin, M.; Le Blanc, K.; Ringden, O.; Barkholt, L.; Omazic, B.; Lergin, C.; Levitsky, V.; Remberger, M. The role of HLA mismatch, splenectomy and recipient Epstein-Barr virus seronegativity as risk factors in post-transplant lymphoproliferative disorder following allogeneic hematopoietic stem cell transplantation. Haematologica 2006, 91, 1059-1067.

104. Hoegh-Petersen, M.; Amin, M.; Liu, Y.; Ugarte-Torres, A.; Williamson, T.; Podgorny, P.; Russell, J.; Grigg, A.; Ritchie, D.; Storek, J. Anti-thymocyte globulins capable of binding to T and B cells reduce graft-vs-host disease without increasing relapse. Bone Marrow Transplant. 2013, 48, 105-114. [CrossRef]

105. Mohty, M. Mechanisms of action of antithymocyte globulin: T-cell depletion and beyond. Leukemia 2007, 21, 1387-1394. [CrossRef]

106. Kekre, N.; Antin, J.H. ATG in allogeneic stem cell transplantation: Standard of care in 2017? Counterpoint. Blood Adv. 2017, 1, 573-576. [CrossRef]

107. Ram, R.; Storb, R. Pharmacologic Prophylaxis Regimens for Acute Graft-Versus-Host Disease: Past, Present and Future; Taylor \& Francis: Oxfordshire, UK, 2013.

108. Shimabukuro-Vornhagen, A.; Hallek, M.J.; Storb, R.F.; von Bergwelt-Baildon, M.S. The role of B cells in the pathogenesis of graft-versus-host disease. Blood 2009, 114, 4919-4927. [CrossRef]

109. Zeiser, R.; Blazar, B.R. Acute graft-versus-host disease-Biologic process, prevention, and therapy. N. Engl. J. Med. 2017, 377, 2167-2179. [CrossRef] [PubMed] 
110. Société Française de Greffe de Moelle et Thérapie Cellulaire. Greffe de Cellules Souches Hématopoïétiques: Livret D'information et D'aide à la Décision à L'usage des Patients; Société Française de Greffe de Moelle et Thérapie Cellulaire: Toulouse, France, 2013.

111. Andréoli, A.L.; de Latour, R.P.; Thépot, S.; Socié, G. La maladie chronique du greffon contre l'hôte. Hématologie 2010, 16, 420-429.

112. Enok Bonong, P.R.; Buteau, C.; Delage, G.; Tanner, J.E.; Lacroix, J.; Duval, M.; Laporte, L.; Tucci, M.; Robitaille, N.; Spinella, P.C.; et al. Transfusion-related Epstein-Barr virus (EBV) infection: A multicenter prospective cohort study among pediatric recipients of hematopoietic stem cell transplants (TREASuRE study). Transfusion 2021, 61, 144-158. [CrossRef]

113. Čičkušić, E.; Mustedanagić-Mujanović, J.; Iljazović, E.; Karasalihović, Z.; Škaljić, I. Association of Hodgkin's lymphoma with Epstein Barr virus infection. Bosn. J. Basic Med. Sci. 2007, 7, 58. [CrossRef]

114. Glaser, S.L.; Lin, R.J.; Stewart, S.L.; Ambinder, R.F.; Jarrett, R.F.; Brousset, P.; Pallesen, G.; Gulley, M.L.; Khan, G.; O'Grady, J. Epstein-Barr virus-associated Hodgkin's disease: Epidemiologic characteristics in international data. Int. J. Cancer 1997, 70, 375-382. [CrossRef]

115. Hakim, H.; Gibson, C.; Pan, J.; Srivastava, K.; Gu, Z.; Bankowski, M.J.; Hayden, R.T. Comparison of various blood compartments and reporting units for the detection and quantification of Epstein-Barr virus in peripheral blood. J. Clin. Microbiol. 2007, 45, 2151-2155. [CrossRef] [PubMed]

116. Greenfield, H.M.; Gharib, M.I.; Turner, A.J.; Guiver, M.; Carr, T.; Will, A.M.; Wynn, R.F. The impact of monitoring Epstein-Barr virus PCR in paediatric bone marrow transplant patients: Can it successfully predict outcome and guide intervention? Pediatr. Blood Cancer 2006, 47, 200-205. [CrossRef] [PubMed] 